ERIA - DP - 2012- 05

ERIA Discussion Paper Series

\title{
Trade Reforms, Competition, and Innovation in the Philippines
}

\author{
Rafaelita M. ALDABA* \\ Philippine Institute for Development Studies, Manila, the Philippines
}

June 2012

\begin{abstract}
What is the impact on firms' innovative activities of the removal of barriers to trade? Does the increase in competition arising from trade reforms lead to increases in innovation? This paper attempts to examine the link between trade liberalization and innovation, using firm panel data on the Philippine manufacturing industry. With the framework of Impulliti and Licandro $(2009,2010)$ as guide, a two-stage approach is tested, where trade and innovation are linked via competition. A reduction in tariffs leads to an increase in competition as price cost margins fall due to the increase in the number of players in the domestic market. With the reduction in price cost margins, profits fall and the productivity threshold above which firms can operate profitably increases. This forces inefficient firms out of the market and resources are reallocated from exiting firms to the higher productivity surviving firms, which innovate at a faster pace. The results show that trade liberalization, has significant positive impact, through competition, on innovation.

Given the crucial role of competition in the relationship between trade liberalization and innovation, it is important for the government to maintain the contestability of markets. The presence of trade barriers or government regulations that limit market entry can create inefficiencies leading to reduced long-term growth. These weaken competition and prevent structural changes from taking place, resulting in resources being tied to low-productivity industries. Weak competition reduces the pressure on firms to adopt new technology or innovate, resulting in low growth of productivity and a loss of competitiveness. Despite two decades of implementing liberalization policy, competition and productivity growth remained weak in the Philippines, not only due to the presence of structural and behavioral barriers to entry, but also to the country's inadequate physical and institutional infrastructure. Due to the fundamental weakness of competition in many major economic sectors, the gains from liberalization remained limited, which slowed down the country's economic growth.

Key Words: Trade, Competition, Innovation, Philippine manufacturing

JEL Classification: L1, O, F1
\end{abstract}

\footnotetext{
The author is grateful to Ms. Estela de Guzman, Director of the Industry and Trade Statistics Department and Ms. Dulce Regala, Chief of the Industry Statistics Division of the National Statistics Office and also acknowledges the research assistance of Mr. Donald Yasay and Ms. Jocelyn Almeda of PIDS.
} 


\section{Introduction}

Innovation is defined as the implementation of a new or significantly improved product or process, a new marketing method, or a new organizational method in business practices, workplace organization or external relations (OECD, 2007). In general, there is broad consensus among economists that research and development/innovation is a major source of economic growth (Gilbert, 2006). As Aghion and Howitt (1999) argue, innovation is a crucial ingredient to long-run economic growth. Moreover, research shows that the social return to investment in $R \& D$ is higher than the private return (Griliches, 1992).

Trade and government policy, along with other factors like institutions, market structure, and market imperfections, can have profound effects on an economic agent's incentives to engage in innovative activities. In the last two decades, we have witnessed rising globalization as countries opened up their economies, creating a new economic environment particularly for developing countries. With the removal of barriers to trade, competition has intensified and has presented both opportunities and challenges to domestic firms to innovate and improve their competitive position.

The number of studies on the impact of trade liberalization on innovation through competition is just starting to grow. The recent literature on trade liberalization looks at its impact on productivity and has increased largely due to the availability of micro data. This body of literature has found that industries facing the greatest tariff reduction and import competition have faster productivity growth than relatively protected industries. This is due to resource allocation arising from the exit of inefficient plants and productivity improvements within existing plants (Pavcnik, 2002 for Chile; Amite and Konings 2007 for Indonesia; Fernandes 2007 for Columbia; among others).

Meanwhile, the theoretical literature on competition and innovation ${ }^{1}$ has shown two contradictory views. On the one hand, the Schumpeterian (1942) view argues that increased competition will reduce profits and the company's incentive to innovate. This view sees monopolies as natural breeding grounds for R\&D. On the other hand, the

\footnotetext{
1 In general, competition and knowledge transfers represent the mechanisms affecting the level of innovation.
} 
opposite view points out that greater competition increases the incentive for firms to innovate in order to survive.Aghion et al. (2006) proposed an inverted U-shaped relationship between competition and innovation. The empirical literature has shown mixed evidence on the relationship between competition and innovation.

Since the 1980s, the Philippines has implemented market-opening reforms such as trade and investment liberalization, deregulation, and privatization in order to encourage competition in the economy, increase productivity and stimulate economic growth. The Philippines has made considerable progress in opening-up the economy to competition not only by removing tariff and non-tariff barriers in the manufacturing and agriculture sectors but also in deregulating and liberalizing infrastructure utilities. At the same time, foreign investment rules were relaxed in almost all sectors particularly in areas reserved only for Filipinos. As a result, the current regime is substantially more open, particularly in manufacturing industry.

Using newly created manufacturing firm-level panel data from the Philippines, the paper will examine the impact of trade reforms through increased competition on domestic firms' innovative activities. The study is relevant given not only the substantial reforms implemented in the last two decades but also in the light of the country's low R\&D expenditures and the urgent need for technology upgrading. The study will address the following question: What is the impact of the removal of barriers to trade on firms' innovative activities? Did the increase in competition arising from trade reforms lead to increases in innovation?

Clearly, there is a need to understand the impact of trade reforms on innovation along with its other determinants, to help the government in properly identifying the necessary policy measures to encourage $R \& D$ investments and technological upgrading in the Philippines. Trade liberalization was one of the major economic reforms carried out in the last two decades. With intense competitive pressures arising from this series of policy changes, understanding their impact on innovation is crucial, particularly since innovation is closely intertwined with growth.

The paper is divided into six parts. After the introduction, section two focuses on the trade and industrial policies and economic performance of the Philippine manufacturing industry. Section three reviews selected literature on competition and 
innovation. Section four presents the methodology of the paper while section five analyzes the results. Section six concludes and discusses the implications of the paper.

\section{Philippine Manufacturing Industry: Trade Policy Reforms, Performance, and Structure}

\subsection{Government Trade Liberalization Policy}

Like most developing countries, the Philippines adopted an import substitution strategy from the 1950s up to the late 1970s. The manufacturing sector is the country's most favored industry given the high level of protection and substantial investment incentives that it enjoyed from the fifties till the eighties. To promote manufacturing growth and development, the government also created regulatory institutions to control prices, domestic supply, and market entry in sectors like cement, passenger cars, trucks, motorcycles, iron and steel, electrical appliances, sugar milling and refining, flour milling, textiles, and paper ${ }^{2}$. This complex maze of protectionist, investment incentive and regulatory policies left a legacy characterized not only by high levels of industrial concentration, and the concentration of economic wealth among a small number of families and groups $^{3}$ but also by the lack of a culture of competition and a weak competition policy framework.

After more than three decades of protectionism and import substitution, the government started to liberalize the trade regime by removing tariff and non-tariff barriers. At the same time, privatization and deregulation policies were implemented. The first tariff reform program (TRP 1) initiated in 1981 substantially reduced the

\footnotetext{
${ }^{2}$ The government deliberately limited the number of industry participants in the motor vehicle, motorcycle, and electrical appliance industries. The government also created a state-controlled monopoly in the iron and steel industry. Textiles was one of the most highly protected sectors which developed under a complex system of import restrictions, foreign exchange controls, tariffs, subsidies, and investment incentives such as easy access to dollar allocations for the industry's raw material and machinery imports, tax concessions, and easy access loans. Collusive agreements in cement and flour were tolerated by the government.

${ }^{3}$ The Foundation for Economic Freedom reported that the richest $15 \%$ of all families account for $53 \%$ of total national income.Claessens et al. (1999) noted that the Ayala family controlled $17 \%$ of total market capitalization while the top ten families in the Philippines controlled 53\% of market capitalization.
} 
average nominal tariff and the high rate of effective protection that characterized the Philippine industrial structure. TRP I also reduced the number of regulated products with the removal of import restrictions on 1,332 lines between 1986 and 1989.

The second phase of the tariff reform program (TRP II) was launched in 1991. TRP II introduced a new tariff code that further narrowed down the tariff range with the majority of tariff lines falling within the three to $30 \%$ tariff range. It also allowed the "tariffication" of quantitative restrictions for 153 agricultural products, and tariff realignment for 48 commodities. With the country's ratification of its membership of the World Trade Organization (WTO) in 1994, the government committed to removal of import restrictions on sensitive agricultural products, except rice, and their replacement with high tariffs. The number of regulated products declined to about $3 \%$ in 1996 and by 1998, most quantitative restrictions were removed, except those for rice.

In 1995, the government initiated another round of tariff reform (TRP III) as a first major step in its plan to adopt a uniform 5\% tariff by 2005. This further narrowed down the tariff range for industrial products to the3to10\% range. In 1996, the government legislated the tariffication of quantitative restrictions imposed on agricultural products, and the creation of tariff quotas imposing a relatively lower duty up to a minimum access level (or in-quota rate), and a higher duty beyond this minimum level (or outquota rate).

In 2001, more legislation (TRP IV) was passed to adjust the tariff structure towards a uniform tariff rate of 5\% by the year 2004, except for a few sensitive agricultural and manufactured items. In October and December 2003, the Arroyo government issued Executive Orders 241 and 264, respectively, to modify the tariff structure such that the tariff rates on products that were not locally produced were made as low as possible while the tariff rates on products that were locally produced were adjusted upward. This resulted in tariff increases on a group of agricultural and manufactured products. As will be shown below, the legislation of EOs 241 and 264 did not lead to any substantial increases in either average nominal or effective protection. However, since many of the tariff increases were made selectively to favor particular industry sectors, the twin EOs hardly made a significant contribution to reducing our highly dispersed tariffs. 
Table 1 presents the statutory tariff rates from 1998 to 2004 for the country's major economic sectors. Note that since 2004, no major "Most Favored Nation" (MFN) tariff changes have been implemented. The tariff changes pursued were mainly those arising from regional trading agreements such as the ASEAN Free Trade Agreement. It is evident from the data that our overall level of tariff rates is already low. The average tariff rate for all industries is $6.82 \%$. Agriculture has the highest average tariff rate of $11.3 \%$. Manufacturing rates are the same as the total industry average with an average tariff rate of $6.76 \%$. Fishing and forestry has an average rate of $6 \%$ while mining and quarrying is the lowest at $2.5 \%$. Unlike the rest of the sectors where "ad valorem" tariffs are used, tariff quotas are used in agriculture primarily because of the increased protection that they can provide against large reductions in import prices.

Table 1: Average Tariff Rates by Major Economic Sector: 1998-2004

\begin{tabular}{lccccccc}
\hline & \multicolumn{7}{c}{ Implementation of Major Tariff Policy Changes } \\
\hline \hline Major Sectors & 1998 & 1999 & 2000 & 2001 & 2002 & 2003 & 2004 \\
All Industries & 11.32 & 10.25 & 8.47 & 8.28 & 6.45 & 6.6 & 6.82 \\
Coefficient of variation & 0.96 & 0.91 & 0.99 & 1.04 & 1.17 & 1.06 & 1.07 \\
\% of tariff peaks & 2.24 & 2.24 & 2.48 & 2.5 & 2.69 & 2.53 & 2.71 \\
Agriculture & 15.9 & 13.2 & 11.5 & 12.3 & 10.4 & 10.4 & 11.3 \\
Coefficient of variation & 1.07 & 1.14 & 1.3 & 1.23 & 1.31 & 1.22 & 1.17 \\
Fishing \& forestry & 9.4 & 8.9 & 6.7 & 6.7 & 5.8 & 5.7 & 6 \\
Coefficient of variation & 0.63 & 0.7 & 0.66 & 0.62 & 0.45 & 0.48 & 0.57 \\
Mining \& quarrying & 3.3 & 3.3 & 3.1 & 3.2 & 2.8 & 2.7 & 2.5 \\
Coefficient of variation & 0.42 & 0.41 & 0.24 & 0.23 & 0.38 & 0.4 & 0.48 \\
Manufacturing & 11.38 & 10.35 & 8.5 & 8.28 & 6.39 & 6.57 & 6.76 \\
Coefficient of variation & 0.93 & 0.88 & 0.95 & 1 & 1.13 & 1.03 & 1.03 \\
\hline Source: Aldaba (2005) & & & & & &
\end{tabular}

Source: Aldaba (2005).

Note, however, that a lower level of tariff protection does not always imply that the tariff schedule is less distorting. The economic and trade distortions associated with our tariff structure depend not only on the size of tariffs but also on the dispersion of these tariffs across all products. Two measures are estimated: the percentage of tariff peaks and the coefficient of variation. Tariff peaks are represented by the proportion of products with tariffs exceeding three times the mean tariff, while the coefficient of variation is the ratio of the standard deviation to the mean. In general, the more 
dispersion in a country's tariff schedule, the greater the distortions caused by tariffs on production and consumption patterns.

As Table 1 shows, while the average tariff rate for all industries dropped from $11.32 \%$ in 1998 to $6.82 \%$ in 2004 , tariff dispersion widened as the coefficient of variation went up from 0.96 to 1.07 . The ad valorem tariffs for mining and quarrying as well as those for fishing and forestry show the most uniformity while those for agriculture and manufacturing exhibit the most dispersion.

Table 1 also indicates that the percentage of tariff peaks (tariffs that are greater than thee times the mean tariff) went up from $2.24 \%$ in 1998 to $2.71 \%$ in 2004 . An increase in the number of tariff peaks occurs when high tariffs are reduced by less than the average reduction over all tariffs. The greater the percentage of tariff peaks in a country's tariff schedule, the greater the potential economic distortions, particularly when highly substitutable products are present in both domestic and world markets. The sectors with tariff peaks consisted mostly of agricultural products with in- and outquota rates. The sectors with tariff peaks consisted of sugarcane, sugar milling and refining, palay, corn, rice and corn milling, vegetables like onions, garlic, and cabbage, roots and tubers, hog, cattle and other livestock, chicken, other poultry and poultry products, slaughtering and meat packing, coffee roasting and processing, meat and meat processing, canning and preserving fruits and vegetables, manufacture of starch and starch products, manufacture of bakery products excluding noodles, manufacture of animal feeds, miscellaneous food products, manufacture of drugs and medicines, manufacture of chemical products, and manufacture and assembly of motor vehicles.

Within the manufacturing sector, the average nominal tariff rates vary, with food manufacturing receiving the highest level of $13.8 \%$ in 2004 while machinery only receives 3\% tariff (see Table 2). The other manufacturing sectors enjoying relatively high average tariff rates include textiles and garments with $11.7 \%$ and furniture and fixtures with $11.2 \%$. The rubber and plastic products sector has an average tariff rate of $9 \%$ while the beverages sector has an average rate of $8.6 \%$. Based on the coefficient of variation, machinery, transportation, food processing, and chemicals and chemical products exhibit the largest dispersion of tariffs while tobacco, textiles and garments, and furniture and fixtures have relatively low dispersion. Note that manufacturing sectors with relatively high coefficients of variation such as machinery and chemical 
and chemical products are the same sectors with the lowest average tariff rates of three and $3.6 \%$, respectively.

Table 2: Structure of Average Tariff Rates in the Manufacturing Sector

\begin{tabular}{|c|c|c|c|c|c|c|c|}
\hline & 1998 & 1999 & 2000 & 2001 & 2002 & 2003 & 2004 \\
\hline Manufacturing & 11.4 & 10.3 & 8.5 & 8.3 & 6.4 & 6.6 & 6.8 \\
\hline $\mathrm{CV}$ & 0.93 & 0.88 & 0.95 & 1 & 1.13 & 1.03 & 1.03 \\
\hline Food manufacturing & 20.8 & 18.2 & 16.1 & 16.5 & 14.4 & 12.9 & 13.8 \\
\hline $\mathrm{CV}$ & 0.98 & 0.92 & 1.06 & 1.08 & 1.2 & 1.08 & 1.01 \\
\hline Beverages & 15.3 & 13.6 & 9.7 & 9.7 & 7 & 7 & 8.6 \\
\hline $\mathrm{CV}$ & 0.41 & 0.5 & 0.52 & 0.52 & 0.44 & 0.44 & 0.53 \\
\hline Tobacco & 18.6 & 13.9 & 9.1 & 9.1 & 6.5 & 6.5 & 7.6 \\
\hline $\mathrm{CV}$ & 0.21 & 0.22 & 0.27 & 0.27 & 0.22 & 0.22 & 0.31 \\
\hline Textile \& garments & 18.8 & 17.6 & 14.3 & 14.1 & 10.6 & 10.9 & 11.7 \\
\hline $\mathrm{CV}$ & 0.38 & 0.31 & 0.43 & 0.46 & 0.45 & 0.48 & 0.42 \\
\hline Leather & 13 & 10.6 & 8.5 & 8.1 & 6.1 & 7.9 & 7.7 \\
\hline $\mathrm{CV}$ & 0.76 & 0.74 & 0.72 & 0.7 & 0.53 & 0.7 & 0.77 \\
\hline Wood & 13.8 & 12.3 & 9.9 & 9.9 & 7.1 & 7.5 & 7.5 \\
\hline $\mathrm{CV}$ & 0.59 & 0.56 & 0.64 & 0.64 & 0.66 & 0.66 & 0.66 \\
\hline Furniture \& fixtures & 19.6 & 16.3 & 15 & 14.4 & 10.8 & 11.1 & 11.2 \\
\hline $\mathrm{CV}$ & 0.39 & 0.36 & 0.45 & 0.48 & 0.49 & 0.45 & 0.44 \\
\hline Paper & 14.2 & 12.1 & 9.4 & 8.9 & 6 & 6.6 & 5.7 \\
\hline $\mathrm{CV}$ & 0.64 & 0.6 & 0.56 & 0.59 & 0.64 & 0.67 & 0.72 \\
\hline Chemicals \& chemical & 4.7 & 4.5 & 3.9 & 3.9 & 3.2 & 3.3 & 3.6 \\
\hline $\mathrm{CV}$ & 0.86 & 0.84 & 0.64 & 0.65 & 0.73 & 0.79 & 1.09 \\
\hline Rubber \& plastic prods & 13.4 & 12.1 & 9.1 & 9.3 & 7.9 & 8.7 & 9 \\
\hline $\mathrm{CV}$ & 0.58 & 0.52 & 0.56 & 0.54 & 0.57 & 0.56 & 0.57 \\
\hline Non-metallic mineral & 9.8 & 9 & 6.7 & 6.4 & 4.8 & 5.7 & 5.7 \\
\hline $\mathrm{CV}$ & 0.8 & 0.77 & 0.69 & 0.7 & 0.6 & 0.76 & 0.77 \\
\hline Basic metals & 10.2 & 9 & 7.8 & 6.9 & 4.9 & 5.4 & 5.3 \\
\hline $\mathrm{CV}$ & 0.74 & 0.73 & 0.73 & 0.78 & 0.74 & 0.82 & 0.83 \\
\hline Machinery & 6.2 & 5.9 & 4.8 & 4.5 & 3 & 3.1 & 3 \\
\hline $\mathrm{CV}$ & 0.99 & 0.96 & 1.03 & 1.01 & 1.16 & 1.23 & 1.27 \\
\hline Transportation & 11.5 & 11.2 & 8.9 & 8.6 & 8.1 & 8.1 & 7.9 \\
\hline $\mathrm{CV}$ & 1.09 & 1.12 & 1.03 & 1.06 & 1.15 & 1.16 & 1.2 \\
\hline Miscellaneous prods & 8.5 & 7.5 & 6 & 5.8 & 4.4 & 4.9 & 5 \\
\hline $\mathrm{CV}$ & 0.89 & 0.81 & 0.8 & 0.82 & 0.76 & 0.83 & 0.9 \\
\hline
\end{tabular}




\subsection{Economic Performance of Manufacturing Industry: 1980s-2000s}

The overall performance of manufacturing industry generally, in terms of output and employment generation has been weak. Table 3 shows that from the 1980s up to the 1990s, manufacturing growth was very slow; averaging $1 \%$ in the 1980 s and $2 \%$ in the 1990s. Growth picked up in the 2000s with manufacturing expanding by $3.4 \%$ on the average. However, there seems to have been very little movement of resources in the manufacturing industry, as its share to total industrial output declined from $26 \%$ in the 1980 s to $25 \%$ in the 1990 s and to about $24 \%$ in the 2000 s. As in manufacturing, growth in the agriculture sector remained sluggish up to the 1990 s and averaging a rate of $4 \%$ during the most recent period. The services sector has been the best performer in all three decades. On average, its growth rate went up from $2.3 \%$ in the 1980 s to $5 \%$ in the 2000s. Broad growth took place as its sub-sectors consistently experienced rising growth rates. Services also accounted for the bulk of the economy's output with the sector's average share rising substantially from $49 \%$ in the 1980 s to $55 \%$ in the current period.

Table 3: Average Value Added Growth Rates and Structure

\begin{tabular}{lcccccc}
\hline & \multicolumn{3}{c}{ Average Growth Rate } & \multicolumn{4}{c}{ Average Value Added Share } \\
\hline \hline Year & $81-89$ & $90-99$ & $00-09$ & $81-89$ & $90-99$ & $00-09$ \\
Agric, Fishery, \&Forestry & 1.3 & 1.5 & 3.5 & $\mathbf{2 3 . 5}$ & $\mathbf{2 1 . 6}$ & $\mathbf{1 9 . 2}$ \\
Industry Sector & 0.9 & 2.1 & 3.9 & $\mathbf{2 7 . 6}$ & $\mathbf{2 6 . 4}$ & $\mathbf{2 5 . 4}$ \\
Mining \& Quarrying & 3 & -1.4 & 12.7 & 1.7 & 1.3 & 1.5 \\
Manufacturing & 0.9 & 2.3 & 3.4 & $\mathbf{2 5 . 9}$ & $\mathbf{2 5 . 1}$ & $\mathbf{2 3 . 8}$ \\
Service Sector & 2.3 & 3.7 & 5.2 & $\mathbf{4 8 . 9}$ & $\mathbf{5 2}$ & $\mathbf{5 5 . 4}$ \\
Construction & -1.4 & 2.9 & 4 & 7.5 & 5.6 & 4.6 \\
Electricity, Gas and Water & 5.3 & 5.3 & 3.7 & 2.6 & 3.1 & 3.2 \\
Transport, Communication \& Storage & 3.7 & 4.4 & 7.6 & 5.3 & 6 & 8.3 \\
Trade & 3 & 3.5 & 5.3 & 13.9 & 15.3 & 16.6 \\
Finance & 2.3 & 5.6 & 6.9 & 3.5 & 4.4 & 5.3 \\
Real Estate & 2.5 & 2.2 & 3.2 & 5.4 & 5.5 & 4.7 \\
Private Services & 5.5 & 3.6 & 3.8 & 6.3 & 7 & 8.1 \\
Government Services & 3.2 & 3.6 & 2.8 & 4.6 & 5.2 & 4.5 \\
TOTAL GDP & $\mathbf{1 . 7}$ & $\mathbf{2 . 8}$ & $\mathbf{4 . 6}$ & $\mathbf{1 0 0}$ & $\mathbf{1 0 0}$ & $\mathbf{1 0 0}$ \\
\hline Source: Nation
\end{tabular}

Source: National Income Accounts, NSCB. 
In terms of employment generation, manufacturing industry failed in creating enough jobs to absorb new entrants to the labor force. Table 4 indicates that its share of total employment remained stagnant at $10 \%$ in the 1980 s till the $1990 \mathrm{~s}$ and dropped to $9.2 \%$ in the $2000-2008$ period. The services sector is the most important provider of employment in the recent period with its average share increasing from $40 \%$ in the 1980 s to $47 \%$ in the 1990 s.Currently it accounts for an average share of almost $54 \%$. Agriculture's share in total employment dropped continuously from $50 \%$ in the 1980 s to $43 \%$ in the 1990 s and to $37 \%$ in the current period.

Table 4: Employment Growth Rate and Structure

\begin{tabular}{lcccccc}
\hline \multirow{2}{*}{ Economic Sector } & \multicolumn{3}{c}{ Average Growth Rate } & \multicolumn{3}{c}{ Average Share } \\
\cline { 2 - 7 } & $81-89$ & $90-99$ & $00-09$ & $81-89$ & $90-99$ & $00-09$ \\
\hline \hline Agriculture, Fish'y, Forestry & $\mathbf{1 . 2}$ & $\mathbf{0 . 7}$ & $\mathbf{1 . 4}$ & $\mathbf{4 9 . 6}$ & $\mathbf{4 2 . 8}$ & $\mathbf{3 6 . 6}$ \\
Industry & 2.5 & 1.7 & 0.8 & 10.6 & 10.6 & 9.6 \\
Mining and Quarrying & 5.3 & -4.6 & 7.9 & 0.7 & 0.5 & 0.4 \\
Manufacturing & $\mathbf{2 . 5}$ & $\mathbf{2 . 1}$ & $\mathbf{0 . 6}$ & $\mathbf{9 . 9}$ & $\mathbf{1 0 . 2}$ & $\mathbf{9 . 2}$ \\
Services & $\mathbf{4 . 8}$ & $\mathbf{4 . 2}$ & $\mathbf{3 . 6}$ & $\mathbf{3 9 . 8}$ & $\mathbf{4 6 . 6}$ & $\mathbf{5 3 . 8}$ \\
Electricity, Gas and Water & $\mathbf{5 . 7}$ & $\mathbf{5 . 7}$ & $\mathbf{3 . 6}$ & $\mathbf{0 . 4}$ & $\mathbf{0 . 4}$ & $\mathbf{0 . 4}$ \\
Construction & $\mathbf{4 . 9}$ & $\mathbf{5 . 3}$ & $\mathbf{2 . 6}$ & $\mathbf{3 . 5}$ & $\mathbf{5}$ & $\mathbf{5 . 2}$ \\
Wholesale \& Retail Trade & 6.2 & 3.8 & 4.6 & 12.5 & 14.6 & 18.4 \\
Transport, Storage \&Com & 4.9 & 6.1 & 3.4 & 4.4 & 5.9 & 7.5 \\
\multicolumn{1}{c}{ Finance, Ins, Real Estate \& Business } & 3.2 & 6.2 & 8 & 1.8 & 2.2 & 3.3 \\
Community, Social \& Personal Services & 4.1 & 3.6 & 2.5 & 17.1 & 18.5 & 19 \\
TOTAL EMPLOYED & 2.7 & 2.5 & 2.5 & 100 & 100 & 100 \\
\hline Source: National Income Accounts, NSCB. & & & & & &
\end{tabular}

Source: National Income Accounts, NSCB.

Table 5 shows the distribution of value added in manufacturing industry. Consumer goods comprised the bulk of manufacturing value added, although their share declined from $57 \%$ to $50 \%$ between the eighties and the $1990 \mathrm{~s}$. In the current period, the sector's share remained at 50\%. Food manufacturing represented the most important sub-sector accounting for an average share of $39 \%$ of the total in the current period. Intermediate goods followed with a share of $27 \%$ in the 2000 s, a decline from $35 \%$ in the 1990 s and $31 \%$ in the $1980 \mathrm{~s}$. Petroleum and coal had the highest average share of $14 \%$ in the 2000s. With the growing importance of electrical machinery, the share of capital goods 
increased steadily from $10 \%$ in the 1980 s to $13 \%$ in the 1990 s and $19 \%$ in the 2000 s. Electrical machinery posted an average growth rate of $3 \%$ in the $1980 \mathrm{~s}, 6 \%$ in the $1990 \mathrm{~s}$, and $12 \%$ in the $2000 \mathrm{~s}$.

\section{Table 5: Average Value Added Structure and Growth}

\begin{tabular}{|c|c|c|c|c|c|c|}
\hline \multirow{2}{*}{ Industry Group } & \multicolumn{3}{|c|}{ Average Growth Rate } & \multicolumn{3}{|c|}{ Average Value Added Share } \\
\hline & $1980-89$ & 1990-99 & $2000-08$ & $1981-89$ & $1990-99$ & $2000-08$ \\
\hline Consumer Goods & $\mathbf{0}$ & 2 & 5 & 57 & 50 & 50 \\
\hline Food manufactures & -1 & 2 & 6 & 44 & 36 & 39 \\
\hline Beverage industries & 7 & 2 & 4 & 4 & 4 & 4 \\
\hline Tobacco manufactures & 1 & 1 & -6 & 3 & 3 & 1 \\
\hline Footwear wearing apparel & 6 & 2 & 2 & 5 & 6 & 5 \\
\hline Furniture and fixtures & 2 & 2 & 7 & 1 & 1 & 1 \\
\hline Intermediate Goods & 2 & 2 & 2 & 31 & 35 & 27 \\
\hline Textile manufactures & 0 & -5 & 0 & 4 & 3 & 2 \\
\hline Wood and cork products & -5 & -4 & -4 & 2 & 2 & 1 \\
\hline Paper and paper products & 4 & -1 & 2 & 1 & 1 & 1 \\
\hline Publishing and printing & 3 & 1 & 0 & 1 & 2 & 1 \\
\hline Leather and leather prod. & -3 & 5 & 0 & 0 & 0 & 0 \\
\hline Rubber products & 1 & -2 & 0 & 2 & 1 & 1 \\
\hline Chemical \& chemical & -1 & 2 & 3 & 7 & 6 & 6 \\
\hline Petroleum \& coal & 6 & 4 & 3 & 12 & 17 & 14 \\
\hline Non-metallic mineral & 2 & 2 & 3 & 2 & 3 & 2 \\
\hline Capital Goods & 2 & 6 & 6 & 10 & 13 & 19 \\
\hline Basic metal industries & 10 & -2 & 13 & 3 & 2 & 2 \\
\hline Metal industries & 4 & 0 & 7 & 2 & 2 & 2 \\
\hline Machinery ex. electrical & 0 & 6 & 2 & 1 & 1 & 2 \\
\hline Electrical machinery & 7 & 13 & 6 & 3 & 6 & 12 \\
\hline Transport equipment & -5 & 2 & 5 & 1 & 1 & 1 \\
\hline Miscellaneous manufactures & 8 & 5 & 7 & 2 & 2 & 3 \\
\hline Total Manufacturing & 1 & 2 & 4 & 100 & 100 & 100 \\
\hline
\end{tabular}

\subsection{Concentration Ratios and Price Cost Margins}

Table 6 presents the domestic concentration ratios covering the years 1988, 1994, and 1998. The year 1988 represents the years prior to the liberalization carried out during the mid-1990s while 1998 represents industrial concentration afterwards. As the figures show, in most sectors, four-firm concentration ratios increased during the entire period under review. On average, the four firm concentration ratio for the 
manufacturing industry went up from $71 \%$ in 1988 to $81 \%$ in 1998 . Petroleum refineries remained almost unchanged. Increases in concentration are observed in tobacco from $97 \%$ to $99.5 \%$, non-electrical machinery from $64 \%$ to $95 \%$, petroleum and coal from $81 \%$ to $100 \%$, other non-metallic from $69 \%$ to $90 \%$ and miscellaneous manufactures from $71 \%$ to $93 \%$. Although decreases are seen in nonferrous metal, industrial chemicals, transport and iron and steel, the sectors remained highly concentrated.

Table 6: CR4 1988, 1994, 1995, and 1998

\begin{tabular}{|c|c|c|c|c|}
\hline Sector & 1988 & 1994 & 1995 & 1998 \\
\hline \multicolumn{5}{|l|}{ High (above 70 percent) } \\
\hline Petroleum Refineries & 100 & 100 & 100 & 99.93 \\
\hline Professional and Scientific & 100 & 100 & 99.97 & 97.41 \\
\hline Tobacco & 96.64 & 99.56 & 99.41 & 99.5 \\
\hline Nonferrous Metal Products & 99.67 & 99.28 & 98.57 & 97.76 \\
\hline Glass and Glass Products & 96.33 & 90.58 & 92.05 & 95.43 \\
\hline Industrial Chemicals & 90.14 & 87.52 & 84.65 & 86.49 \\
\hline Transport Equipment & 80.98 & 86.2 & 84.4 & 77.67 \\
\hline Pottery, China and Earthen & 92.82 & 86.05 & 93.74 & d \\
\hline Food Processing & 79.51 & 81.37 & 81.74 & $\mathrm{a}$ \\
\hline Iron and Steel & 84.18 & 80.64 & 70.55 & 79.43 \\
\hline Machinery except Electrical & 63.59 & 77.47 & 79.43 & 94.9 \\
\hline Petroleum and Coal Products & 81.1 & 77 & 87.4 & 100 \\
\hline Fabricated Metal Products & 73.45 & 74.48 & 74.32 & 78.24 \\
\hline Other Chemicals & 66.37 & 75.64 & 69.09 & 80.92 \\
\hline Rubber Products & 79.15 & 73.5 & 73.66 & 90.33 \\
\hline Other Nonmetallic Mineral & 68.92 & 71.31 & 74.54 & $90.03^{d}$ \\
\hline Paper and Paper Products & 78.97 & 71.23 & 70.4 & 78.14 \\
\hline Miscellaneous Manufacture & 70.87 & 70.62 & 76.76 & 92.77 \\
\hline Textiles & 64.12 & 64.14 & 72.37 & 72.84 \\
\hline Food Manufacturing & 63.48 & 69.74 & 77.92 & $86.94^{\mathrm{a}}$ \\
\hline Beverages & 48.19 & 70.08 & 63.43 & 73.51 \\
\hline Electrical Machinery & 64.8 & 69.36 & 63.73 & 72.42 \\
\hline Leather and Leather Products & 57.7 & 63.89 & 64.02 & $73.47^{\mathrm{c}}$ \\
\hline Wood and Cork Products & 40.5 & 55.47 & 65.35 & 76.32 \\
\hline
\end{tabular}


Table 6: (continued) CR4 1988, 1994, 1995, and 1998

\begin{tabular}{lcccc}
\hline \multicolumn{1}{c}{ Sector } & 1988 & 1994 & 1995 & 1998 \\
\hline \hline Printing and Publishing & 42.13 & 47.26 & 51.08 & 82.08 \\
Plastic Products & 49.41 & 40.75 & 50.87 & 70.09 \\
Moderate (40 percent to 69 percent) & & & & \\
Metal Furniture & 80.88 & 79.49 & 62.67 & $\mathrm{~b}$ \\
Cement & 45.3 & 48.3 & 45.37 & 68.22 \\
Leather Footwear & 30.33 & 41.7 & 55 & $\mathrm{c}$ \\
Furniture & 19.51 & 40.91 & 41.64 & $62.54^{\mathrm{b}}$ \\
Low (below 39 percent) & & & & \\
Wearing Apparel except Footwear & 34.7 & 31.69 & 26.52 & 23.57 \\
Total Manufacturing & 70.88 & 73.63 & 73.64 & 80.55 \\
\hline
\end{tabular}

Source of basic data:National Statistics Office, 1988 and 1994 Census of Establishments and 1995 and 1998 Annual Survey of Establishments. The concentration ratios refer to the ratio of census value added by four largest firms to total in each five-digit PSIC sector. The concentration ratios given above are weighted averages for three-digit PSIC.

acombined food manufacturing and food processing;

$\mathrm{b}$ combined metal furniture and furniture;

${ }^{c}$ combined leather footwear and leather products ;

${ }^{d}$ combined pottery, china and other nonmetallic products

As discussed earlier, the average tariffs rates have been substantially reduced to low levels. Table 7 presents four-firm concentration ratio (CR4) calculations for manufacturing industry adjusted for the presence of imports. In general, given the relatively low tariff rates affecting manufacturing industry the calculated ratios seem to indicate that the industry is already contestable. In most sectors, the concentration ratios are below $35 \%$ such as in paper \& paper products, rubber \& plastic, medical \& precision instruments, basic metals, and machinery and equipment not elsewhere specified (nec), while fabricated metal products and publishing \& printing are about $36 \%$. For chemicals \& chemical products, $41 \%$; other transport equipment, about $45 \%$; and for motor vehicles, non-metallic and food products, the concentration ratios range from 54 to $57 \%$. However, high ratios ranging from $60-82 \%$ are still prevalent in sectors such as refined petroleum, tobacco, beverages, and flat glass (non-metallic products). 
Table 7: Four Firm Concentration Ratios (2003)

\begin{tabular}{|c|c|c|}
\hline PSIC & Description & CR4 \\
\hline 23 & Coke, Refined Petroleum and other Fuel Products & 79.8 \\
\hline 16 & Tobacco Products & 72 \\
\hline 15 & Beverages & 62.4 \\
\hline 26 & Other non-metallic: flat glass & 82.4 \\
\hline 34 & Motor Vehicles, Trailers, and Semi-trailers & 57.2 \\
\hline 15 & Food & 55.7 \\
\hline 26 & Other Non-Metallic Mineral products & 54.3 \\
\hline 26 & Other non-metallic: cement & 52.7 \\
\hline 19 & Tanning and Dressing of Leather; Luggage, Handbags and Footwear & 45.1 \\
\hline 35 & Manufacture of Other Transport Equipment & 44.8 \\
\hline 24 & Chemicals and Chemical Products & 40.6 \\
\hline 22 & Publishing, Printing and Reproduction of Recorded Media & 36.3 \\
\hline 28 & Fabricated Metal Products, Except Machinery and Equipment & 35.8 \\
\hline 29 & Machinery and Equipment, n.e.c. & 34.5 \\
\hline 27 & Basic Metals & 30.5 \\
\hline 33 & Medical, Precision and Optical Instruments, Watches and Clocks & 29.4 \\
\hline 21 & Paper and Paper Products & 29 \\
\hline 25 & Rubber and Plastic Products & 28.3 \\
\hline 36 & Manufacture and Repair of Furniture & 22.7 \\
\hline 20 & $\begin{array}{l}\text { Wood, Wood Products and Cork, Except Furniture; Articles of Bamboo, Cane, Rattan and the } \\
\text { Like; Plaiting Materials }\end{array}$ & 20.4 \\
\hline 17 & Textile & 4.4 \\
\hline
\end{tabular}

CR4 $=4$-firm concentration ratio calculated as the value of output by the four largest firms to the total for each 5-digit industry level. The CR4 calculations are adjusted for import penetration (MPR), i.e., (1-MPR)*CR4. Import penetration shares are estimated as the ratio of imports to output plus imports less exports.

Table 8 presents price cost margin (PCM) estimates with an average of $29 \%$ for manufacturing industry.In a number of sectors, PCMs are already low in 2003, ranging from 8 to $19 \%$ covering leather, fabricated metal, transport equipment, garments, machinery (excluding electrical), and printing and publishing.Moderate PCMs that range from 22 to $38 \%$ are found in food, plastic, wood, rubber, and furniture products. Finally, PCMs are high in beverages, tobacco, non-metallic products (including cement), and glass and glass products. In these sectors, PCMs range from 45 to $62 \%$. These sectors are also the most highly concentrated within manufacturing industry. 
Table 8: Price Cost Margins

\begin{tabular}{|c|c|c|c|c|}
\hline Code & Description & $\begin{array}{c}\text { PCM based on Roeger } \\
\text { method }\end{array}$ & $\begin{array}{l}\text { Standard } \\
\text { Errors }\end{array}$ & $\begin{array}{l}\text { PCM based on } \\
\text { simple method }\end{array}$ \\
\hline 313 & Beverages & $0.62^{* * *}$ & 0.06 & 0.53 \\
\hline 314 & Tobacco & $0.59^{* * *}$ & 0.04 & 0.47 \\
\hline $361,363 \& 369$ & Pottery, cement \& other nonmetallic & $0.60^{* * *}$ & 0.1 & 0.57 \\
\hline 362 & Glass and Glass Products & $0.50^{* * *}$ & 0.04 & 0.52 \\
\hline 352 & Other chemicals & $0.45^{* * *}$ & 0.04 & 0.37 \\
\hline 341 & Paper and Paper Products & $0.38^{* * *}$ & 0.03 & 0.36 \\
\hline 351 & Industrial chemicals & $0.38^{* * *}$ & 0.03 & 0.35 \\
\hline 355 & Rubber products & $0.34^{* * *}$ & 0.05 & 0.28 \\
\hline $332 \& 386$ & Furniture including Metal Furniture & $0.32^{* * *}$ & 0.03 & 0.22 \\
\hline 385 & Professional and Scientific equipment & $0.31^{* * *}$ & 0.29 & -0.06 \\
\hline 331 & Wood and Cork & $0.31^{* * *}$ & 0.02 & 0.26 \\
\hline 372 & Nonferrous metal & $0.31^{* * *}$ & 0.05 & 0.21 \\
\hline 390 & Miscellaneous manufactures & $0.30^{* * *}$ & 0.04 & 0.2 \\
\hline 356 & Plastic products & $0.30^{* * *}$ & 0.02 & 0.25 \\
\hline 353 & Petroleum refineries & $0.29^{* * *}$ & 0.11 & 0.21 \\
\hline 383 & Electrical machinery & $0.28^{* * *}$ & 0.01 & 0.25 \\
\hline 354 & Petroleum and Coal & $0.27^{* * *}$ & 0.12 & 0.21 \\
\hline 321 & Textiles & $0.26^{* * *}$ & 0.02 & 0.27 \\
\hline $311 \& 312$ & Food processing \& manufacturing & $0.24^{* * *}$ & 0.03 & 0.28 \\
\hline 371 & Iron and Steel & $0.22^{* * *}$ & 0.01 & 0.26 \\
\hline 342 & Printing and Publishing & $0.19^{* *}$ & 0.11 & 0.16 \\
\hline 382 & Machinery except Electrical & $0.18^{* * *}$ & 0.04 & 0.11 \\
\hline 322 & Wearing Apparel except Footwear & $0.16^{* *}$ & 0.12 & -0.01 \\
\hline 384 & Transport equipment & $0.12^{* * *}$ & 0.04 & 0.14 \\
\hline 381 & Fabricated metal & $0.10^{* *}$ & 0.04 & 0.17 \\
\hline \multirow[t]{2}{*}{$323 \& 324$} & Leather \& leather footwear & $0.08^{* * *}$ & 0.04 & 0.16 \\
\hline & All manufacturing & $0.29^{* * *}$ & 0.02 & 0.3 \\
\hline
\end{tabular}

Note:PCMs in column 3 are estimated using Roeger regression while those in column 4 are based on accounting data using average variable costs as proxy for marginal costs. *** indicates significance at the $1 \%$ level.

Source: Aldaba (2008). 


\subsection{Total Factor Productivity Growth}

Table 9 presents estimates of Total Factor Productivity (TFP) growth. The growth figures are normalized and interpreted as growth relative to 1996. From 1996 to 2006, aggregate productivity gains are evident in the leather, textiles, furniture, other manufacturing, and basic and fabricated metal sectors. Leather grew by $9.5 \%$, textiles by $2.4 \%$, other manufacturing by $2.9 \%$, furniture by $1.9 \%$ and basic metals by $1.3 \%$. Meanwhile, six sectors covering food, beverages, and tobacco; garments; wood, paper, and publishing; coke, petroleum, chemicals and rubber; non-metallic products; basic and fabricated metal products as well as machinery and equipment, motor vehicle and other transport registered negative productivity growth rates from 1996 to 2006 . On the whole, the manufacturing sector's aggregate productivity declined by 3.4\% from 1996 to 2006 . 
Table 9: Total Factor Productivity Growth

\begin{tabular}{|c|c|c|c|c|c|}
\hline Sector & Year & TFP Growth relative to base year 1996 & Sector & Year & TFP Growth relative to base year 1996 \\
\hline \multirow{8}{*}{$\begin{array}{l}\text { Food, beverages, \& } \\
\text { tobacco }\end{array}$} & 1996 & 0 & \multirow[t]{8}{*}{ Non-metallic products } & 1996 & 0 \\
\hline & 1997 & 0.45 & & 1997 & 0.11 \\
\hline & 1998 & 3.01 & & 1998 & 1.47 \\
\hline & 2000 & -0.82 & & 2000 & -1.12 \\
\hline & 2002 & -1.83 & & 2002 & -7.38 \\
\hline & 2003 & -2.25 & & 2003 & -2.2 \\
\hline & 2005 & -1.36 & & 2005 & 0.39 \\
\hline & 2006 & -1.44 & & 2006 & -0.65 \\
\hline \multirow[t]{7}{*}{ Textile } & 1996 & 0 & \multirow[t]{7}{*}{ Basic metal \& fabricated metal products } & 1996 & 0 \\
\hline & 1997 & 1.8 & & 1997 & -0.2 \\
\hline & 1998 & 1.01 & & 1998 & -4.39 \\
\hline & 2000 & 0.95 & & 2000 & -1.77 \\
\hline & 2002 & -0.46 & & 2002 & -3.18 \\
\hline & 2005 & 6 & & 2005 & -4.47 \\
\hline & 2006 & 2.35 & & 2006 & 1.32 \\
\hline \multirow[t]{8}{*}{ Garments } & 1996 & 0 & \multirow[t]{8}{*}{ Machinery \& equipment, motor vehicles \& other } & 1996 & 0 \\
\hline & 1997 & 1.12 & & 1997 & 0.37 \\
\hline & 1998 & 2.46 & & 1998 & -4.92 \\
\hline & 2000 & 0.51 & & 2000 & 0.9 \\
\hline & 2002 & 0.49 & & 2002 & -2 \\
\hline & 2003 & 0.62 & & 2003 & -2.75 \\
\hline & 2005 & -0.75 & & 2005 & -1.7 \\
\hline & 2006 & -0.99 & & 2006 & -0.86 \\
\hline
\end{tabular}


Table 9: (continued) Total Factor Productivity Growth

\begin{tabular}{|c|c|c|c|c|c|}
\hline Sector & Year & TFP Growth relative to base year 1996 & Sector & Year & TFP Growth relative to base year 1996 \\
\hline \multirow[t]{7}{*}{ Leather } & 1996 & 0 & Furniture & 1996 & 0 \\
\hline & 1997 & -1.35 & & 1997 & 1.16 \\
\hline & 1998 & 0.81 & & 1998 & 1.64 \\
\hline & 2000 & 0.63 & & 2000 & 3.12 \\
\hline & 2002 & 7.2 & & 2002 & 3.46 \\
\hline & 2003 & 12.1 & & 2003 & 2.03 \\
\hline & 2006 & 9.54 & & 2006 & 1.86 \\
\hline \multirow{7}{*}{$\begin{array}{l}\text { Wood, paper, \& } \\
\text { publishing }\end{array}$} & 1996 & 0 & Other manufacturing & 1996 & 0 \\
\hline & 1997 & 0.61 & & 1997 & -0.18 \\
\hline & 1998 & 0.29 & & 1998 & 3.01 \\
\hline & 2000 & -2.46 & & 2000 & 0.27 \\
\hline & 2002 & -1.06 & & 2002 & 1.49 \\
\hline & 2005 & -3.64 & & 2005 & 1.18 \\
\hline & 2006 & -5.39 & & 2006 & 2.87 \\
\hline \multirow{8}{*}{$\begin{array}{l}\text { Coke, petroleum, } \\
\text { chemicals \& rubber }\end{array}$} & 1996 & 0 & All manufacturing & 1996 & 0 \\
\hline & 1997 & -0.61 & & 1997 & -0.23 \\
\hline & 1998 & -2.68 & & 1998 & -1.59 \\
\hline & 2000 & 2.94 & & 2000 & -0.44 \\
\hline & 2002 & -6.65 & & 2002 & -4.86 \\
\hline & 2003 & 4.19 & & 2003 & -1 \\
\hline & 2005 & -1.11 & & 2005 & -2.53 \\
\hline & 2006 & -4.76 & & 2006 & -3.37 \\
\hline
\end{tabular}

Source:Aldaba (2010).

Note: These growth figures are normalized and interpreted as growth relative to base year 1996. 


\subsection{R\&D/Innovation}

The indicators most commonly used to monitor the resources devoted to Research and Development (R\&D) are given by the gross domestic expenditure on R\&D and R\&D intensity measured by the percentage of GDP devoted to R\&D. Table 10 presents these two indicators for the Philippines, along with its neighbors in Southeast Asia. Research intensity is low in the Philippines with investment in $R \& D$ declining from $0.15 \%$ in 2002 to $0.12 \%$ in 2005 . Singapore is the most research intensive as its ratio almost doubled between 1996 and 2007 from 1.37 to 2.61, respectively. In terms of R\&D expenditures per capita, the Philippines and Indonesia registered the lowest figures with the Philippines declining from purchasing power parity \$(PPP\$) 4 in 2002 to PPP\$3 in 2005.

Table 10: R\&D as Percentage of GDP and R\&D per Capita

Data: Gross Domestic Expenditure on R\&D as a percentage of GDP

\begin{tabular}{cccccc}
\hline Year & PHIL & SING & THAI & MAL & INDO \\
\hline 1996 & $\ldots$ & 1.37 & 0.12 & 0.22 & $\ldots$ \\
1997 & $\ldots$ & 1.48 & 0.1 & $\ldots$ & $\ldots$ \\
1998 & $\ldots$ & 1.81 & $\ldots$ & 0.4 & $\ldots$ \\
1999 & $\ldots$ & 1.9 & 0.26 & $\ldots$ & $\ldots .07$ \\
2000 & $\ldots$ & 1.88 & 0.25 & 0.49 & 0.05 \\
2001 & $\ldots$ & 2.11 & 0.26 & $\ldots$ & $\ldots$ \\
2002 & $\ldots .15$ & 2.15 & 0.24 & 0.69 & $\ldots$ \\
2003 & $\ldots .14$ & 2.11 & 0.26 & $\ldots$ & $\ldots$ \\
2004 & $\ldots$ & 2.2 & 0.26 & $\ldots$ & $\ldots$ \\
2005 & $\ldots .12$ & 2.3 & 0.23 & 0.6 & $\ldots$ \\
2006 & $\ldots$ & 2.31 & 0.25 & & $\ldots$ \\
\hline
\end{tabular}


Table 10: (continued) R\&D as Percentage of GDP and R\&D per Capita

Data: Gross Domestic Expenditure on R\&D per capita (in PPP\$)

\begin{tabular}{|c|c|c|c|c|c|}
\hline Year & PHIL & SING & THAI & MAL & INDO \\
\hline 1996 & $\ldots$ & 384 & 6 & 18 & $\ldots$ \\
\hline 1997 & $\ldots$ & 440 & 5 & $\ldots$ & $\ldots$ \\
\hline 1998 & $\ldots$ & 520 & $\ldots$ & 32 & $\ldots$ \\
\hline 1999 & $\ldots$ & 578 & 12 & $\ldots$ & $\ldots$ \\
\hline 2000 & $\ldots$ & 632 & 12 & 45 & 2 \\
\hline 2001 & $\ldots$ & 696 & 13 & $\ldots$ & 1 \\
\hline 2002 & 4 & 747 & 13 & 67 & $\ldots$ \\
\hline 2003 & 4 & 764 & 15 & $\ldots$ & $\ldots$ \\
\hline 2004 & $\ldots$ & 882 & 16 & 66 & $\ldots$ \\
\hline 2005 & 3 & 996 & 16 & $\ldots$ & 2 \\
\hline 2006 & $\ldots$ & 1104 & 18 & 80 & $\ldots$ \\
\hline 2007 & $\ldots$ & 1342 & $\ldots$ & $\ldots$ & $\ldots$ \\
\hline
\end{tabular}

Source: UNESCO Institute for Statistics.

Table 11 presents the number of researchers (measured in full-time equivalent). In the Philippines, this increased to 6896 in 2005 from 5860 in 2003. Expressed in terms of researchers per million inhabitants, this went up from 71 in 2003 to 81 in 2005 for the Philippines. In Singapore, this went up significantly from 2,535 in 1996 to 5,575 in 2005 and to 6,088 in 1007. In Thailand, the ratio increased from 100 in 1996 to 311 in 2005. In Malaysia, this was 503 in 2004 and 205 in Indonesia in 2001. 
Table 11: Number of Researchers

Data: Researchers (Full Time Equivalent) - Total

\begin{tabular}{cccccc}
\hline YEAR & PHILS & SING & THAI & MAL & INDO \\
\hline \hline 1996 & $\ldots$ & 9108 & 6038 & 1894 & $\ldots$ \\
1997 & $\ldots$ & 9704 & 4409 & $\ldots$ & $\ldots$ \\
1998 & $\ldots$ & 11396 & $\ldots$ & 3416 & $\ldots$ \\
1999 & $\ldots$ & 12598 & 10418 & $\ldots$ & $\ldots$ \\
2000 & $\ldots$ & 16633 & $\ldots$ & 6423 & 44984 \\
2001 & $\ldots$ & 16740 & 17710 & $\ldots$ & 42722 \\
2002 & $\ldots$ & 18120 & $\ldots$ & 7157 & $\ldots$ \\
2003 & 5860 & 20024 & 18114 & $\ldots$ & $\ldots$ \\
2004 & $\ldots$ & 21359 & $\ldots$ & 12670 & $\ldots$ \\
2005 & 6896 & 23789 & 20506 & $\ldots$ & $\ldots$ \\
2006 & $\ldots$ & 25033 & $\ldots$ & 9694 & $\ldots$ \\
2007 & $\ldots$ & 27301 & $\ldots$ & $\ldots$ & $\ldots$ \\
\hline
\end{tabular}

Data: Researchers per million inhabitants (Full Time Equivalent)

\begin{tabular}{cccccc}
\hline YEAR & PHILS & SING & THAI & MAL & INDO \\
\hline \hline 1996 & $\ldots$ & 2535 & 100 & 90 & $\ldots$ \\
1997 & $\ldots$ & 2615 & 72 & $\ldots$ & $\ldots$ \\
1998 & $\ldots$ & 2977 & $\ldots$ & 154 & $\ldots$ \\
1999 & $\ldots$ & 3203 & 169 & $\ldots$ & $\ldots$ \\
2000 & $\ldots$ & 4139 & $\ldots$ & 276 & 219 \\
2001 & $\ldots$ & 4103 & 281 & $\ldots$ & 205 \\
2002 & $\ldots$ & 4398 & $\ldots$ & 295 & $\ldots$ \\
2003 & 71 & 4820 & 281 & $\ldots$ & $\ldots$ \\
2004 & $\ldots$ & 5087 & $\ldots$ & 503 & $\ldots$ \\
2005 & 81 & 5575 & 311 & $\ldots$ & $\ldots$ \\
2006 & $\ldots$ & 5736 & $\ldots$ & 372 & $\ldots$ \\
2007 & $\ldots$ & 6088 & $\ldots$ & $\ldots$ & $\ldots$ \\
\hline
\end{tabular}

Source: UNESCO Institute for Statistics.

These figures tend to indicate that the Philippines have been under-investing in R\&D. In a study on R\&D gaps in the Philippines, Cororaton (1999) estimated a gap of $0.6 \%$ of GDP based on the average ratio in the 1980 s. In terms of R\&D manpower, the 
results showed the need for an additional 197 scientists and engineers per million populations based on the average level in the 1980s. Cororaton also pointed out the large gap in the country's institutional structure characterized by a weak national science and technology system including incentives and protection of intellectual property rights.

\section{Brief Review Of Selected Literature}

There are three strands of literature on international trade and growth that are important in assessing the effects of trade liberalization on innovation: trade and competition, competition and innovation, and trade and innovation.

\section{Competition and Innovation}

The existing theoretical models on competition and innovation point to two opposing views. Early endogenous growth and Industrial Organization models suggested that competition appears to be detrimental to innovation and technical progress. Rents are seen as the major source of innovation for companies wishing to engage in R\&D. Increased competition leads to a decline in innovative activity as more competition reduces the monopoly rents that reward successful innovators. Hence, large firms provide a more stable platform for investment in R\&D. In contrast, the opposite view contends that competition may foster innovation as firms need to escape increased competition from rival firms. Competition will force firms to innovate in order to survive.

In an effort to reconcile the two views, Aghion et al. (2001) extended the basic Shumpeterian model by allowing incumbent firms to innovate. Traditional models were based on the assumption that innovation was done by outsiders or new entrants competing against incumbents with conventional technology and that the payoff of innovation was equal to the post-innovation rent (pre-innovation rent was zero). The Aghion et al. model assumes that innovation incentives depend on the difference between post-innovation and pre-innovation rents. Firms innovate to reduce production 
costs and this is done in a step-by-step manner where a laggard firm must first catch up with the technological leader before becoming a leader. Greater competition may foster innovation and growth as it may reduce a firm's pre-innovation rents by more than it reduces post-innovation rents. Competition may increase the incremental profits from innovation and encourage $\mathrm{R} \& \mathrm{D}$ investments aimed at escaping competition. Competition is particularly intense in "neck-and-neck" industries, where competition is so close that it is hardly possible to determine which firm is leader, and the "escape competition" effect is strongest in these industries. On the other hand, in less neck-andneck or unleveled industries, more competition may reduce innovation as the reward for laggard firms catching up with the technological leader may fall; this is the Schumpeterian effect.

The model predicts an inverted-U shaped relationship between competition and innovation. At low levels of competition, the "escape competition" effect dominates while at higher levels of competition, the "Schumpeterian effect" dominates. To test the model, Aghion et al. (2002) used a panel dataset of UK firms. The results confirmed the presence of a strong inverted $U$ relationship and the gradient of the curve tends to be steeper for firms that are in more neck-and-neck industries. Looking at entry and innovation, Aghion and Burgess (2003) showed that competition can affect innovation depending on the firm's level of efficiency. In particular, firms close to the efficiency frontier are expected to survive and deter entry by innovating. An increased entry threat leads to greater innovation aimed at escaping that threat. In contrast, firms that are far below the frontier are in a weaker position to fight external entry. An increased entry threat reduces the payoff from innovating, since the innovation's expected life horizon has become shorter. Competition thus provides incentives for more efficient firms to innovate and a disincentive for less efficient ones. In a related model, Aghion et al. (2005) predict that firms located in more pro-business environments are more likely to respond to competition by innovating.

Empirical studies that investigated the relationship between competition and innovation showed mixed results. The Schumpeterian argument predicts a negative relationship. Earlier studies that used market concentration as proxy for competition showed a positive relationship between industry concentration and R\&D intensity (implying a negative relationship). However, more recent studies showed that this 
disappears when inter-industry differences such as industry characteristics and technological opportunities are taken into account (Gilbert, 2006). Geroski (1990) did not find support for the Schumpeterian assertion that monopoly power stimulates innovation. More recent empirical studies on the relationship between competition and innovation pointed to a positive relationship. Empirical work by Geroski (1995), Nickell (1996), and Blundell et al. (1999) found a positive correlation between competition and innovation. Creusen et al. (2006) also found a positive relationship between competition and innovation but no evidence for the existence of an inverted U.

Hopman and Rojas-Romagosa (2010) analyzed the relationship between changes in competition levels and innovation efforts. Using OECD panel data, the authors found a monotonic relationship between the variables, but did not find an inverted-U relationship as in the influential Aghion et al. (2001) paper. Gorodnichenko et al. (2009) tested predictions about the impact of competition and linkages with foreign firms on domestic firms' innovative efforts, using data on firms in 27 transition economies. Their findings showed that competition has a negative effect on innovation, especially for firms that are far from the efficiency frontier. Firms that have market power tend to innovate more, but greater pressure from foreign competition also stimulates innovation. The paper did not find support for an inverted $U$ effect of competition on innovation. Carlin, Schaeffer and Seabright (2004) also tested the inverted $U$ hypothesis using data on transition economies. The results showed that innovation is higher in monopolistic industries.

In the Philippines, similar studies linking competition and innovation have not yet been done. Research work on innovation focused on the estimation of the R\&D gap (Cororaton, 1999) as well as analysis of the state of science and technology and R\&D in the country along with recommendations on how to improve the innovation system and how to catch up (Cororaton, 2002; Patalinghug, 1999 and 2003; and Macapanpan, 1999). These studies show that the government's science and technology(S\&T) policy lacks focus and does not provide clear direction for technology innovation. As such, it has failed to encourage private sector participation despite the R\&D incentives granted. Institutional mechanisms are weak with lack of coordination of planning and budgeting activities. Major recommendations include improvements in R\&D investment, 
manpower, the incentive system, institutional arrangements and S\&T coordination mechanisms.

\section{Trade and Competition}

Since the early 1980s, the new trade theory has shown that aside from the gains from trade due to specialization based on comparative advantage, trade liberalization can lead to additional gains by reducing the "deadweight losses" created by the ability of domestic firms to exercise market power.An open trade regime is a powerful instrument for disciplining the firms that have market power. Competition from imports constrains the ability of domestic producers to engage in anti-competitive activities which would otherwise reduce welfare (Cadot, Grether, \& de Melo, 2000). This is known in the Industrial Organization literature as the "imports-as-competitive discipline" hypothesis. When confronted with intensified competition, domestic industries which may have accumulated oligopoly profits in heavily protected markets, are forced to behave more competitively.

Most of the empirical work on the imports-as-competitive discipline hypothesis focus on profitability regressions, which regress a measure of profitability such as price cost margin on import penetration (the ratio of imports to domestic consumption), as a proxy for trade policy and intensity of import competition and other factors affecting industry profitability. Since marginal costs are not observable, mark-ups are only inferred indirectly from price cost margins. Other proxies used for trade policy include effective protection rates, tariff rates, or import license coverage ratios.

In general, the empirical evidence provides strong support for the imports-ascompetitive discipline hypothesis.Based on industry-levelcross-section data, Schmalensee (1989) indicated that the ratio of imports to domestic consumption tends to be negatively correlated with the profitability of domestic sellers, especially when domestic concentration is high. Pugel (1980) also found that import penetration has a stronger negative relationship with domestic profitability when conventional measures of entry barriers are high.

Reviewing the literature on the impact of trade liberalization on price cost margins, Erdem and Tybout (2003) and Tybout (2001) concluded that based on numerous empirical studies of firm- and plant-level liberalization episodes, mark-ups decline with 
import competition and this empirical evidence provide robust confirmation for the import discipline hypothesis. Among import-competing firms, trade liberalization squeezes price cost margins, inducing some intra-plant efficiency gains as well as additional efficiency gains due to the closure of weak plants. The authors added that the effect was particularly marked among large plants. As Roberts and Tybout (1996) wrote in an earlier paper, in every country studied, relatively high industry-wide exposure to foreign competition is associated with lower margins and the effect is concentrated in larger plants.

Using panel data sets on firms, Harrison (1994) examined the results for Cote d'Ivoire and Krishna and Mitra (1998) for India. Harrison found that mark-ups were negatively related to import competition in Cote d'Ivoire.In India, Krishna and Mitra also showed that mark ups fell during the trade reform period.Earlier studies by De Melo and Urata (1986) and Tybout (1996) for Chile and Grether (1996) for Mexico showed the same finding. Erdem and Tybout (2003) cautioned that care must be exercised in interpreting the results. The authors noted that the studies only describe the short-run effects of trade liberalization. Reforms in trade regimes trigger a dynamic adjustment process that may take a long time to play out (plausibly lasting more than a decade).

Other studies showing further evidence that trade liberalization has a procompetitive effect include those carried out by Levinsohn (1993) for Turkey; Warzynski (2002) and J. Konings, Vanseele, and Warzynski (2002) for Romania and Bulgaria; as well as Goldar and Agarwal (2004), Kambhampati and Parikh (2003), and Srivastava et al. (2001) for India. These country studies provide support to the import discipline hypothesis that trade liberalization can lead to substantial reductions in price cost margins at least in those industries that are imperfectly competitive. For the Philippines, Aldaba (2007) confirmed the same finding that price cost margins fall with import competition, and that trade liberalization has a disciplining effect on firms' pricing behavior.

With the availability of micro data, the recent literature on trade liberalization and productivity has increased substantially. This body of literature shows that industries facing the greatest tariff reduction and import competition have faster productivity growth than relatively protected industries. This is due to resource allocation arising 
from the exit of inefficient plants and productivity improvements within existing plants. Empirical studies showing these results were pioneered by Pavcnik (2002) for Chile; Topalova (2003) for India; Muendler (2002) and Amite and Konings (2007) for Indonesia, Schor (2003) for Brazil and Fernandes (2007) for Columbia. For the Philippines, Aldaba (2010) also provided some evidence that trade liberalization leads to productivity increases. Trade liberalization drives the process of restructuring and reshuffling of resources within and across sectors of the economy such that unprofitable activities contract while profitable ones expand. Trade liberalization allows more productive firms to expand while less efficient firms either exit or shrink. With the exit of inefficient firms, resources (labor and capital) will be freed and will move to other industries where they can be used more productively.

\section{Trade and Innovation}

Recent literature on trade and growth shows that international trade affects firms' innovative activities through increased competition. As Licandro (2010) noted, increasing evidence supports the claim that international trade enhances innovation and productivity growth through an increase in competition.

In an earlier work based on Schumpeterian growth theory and using firm panel datasets for India and the UK, Aghion and Burgess (2003) found that reducing barriers to entry to foreign products and firms has a more positive effect on economic performance for firms and industries that are initially closer to the technological frontier. Incumbent firms that are sufficiently close to the technological frontier can survive and deter entry by innovating. On the other hand, firms that are far below the frontier are in a weaker position to fight external entry since this will reduce their expected payoff from innovating. Thus liberalization encourages innovation in industries that are close to the frontier and discourages innovation in industries that are far from it. Productivity, outputs, and profits should be higher in the industries and firms that are initially more advanced. The authors suggested that for countries to benefit from liberalization, policies that allow firms to upgrade their technological capabilities or which allow workers to move from low to high productivity sectors are important. 
Griffith, Harrison and Simpson (2006) assessed the impact of product market reforms under the European Union's (EU)'s Single Market Programme (SMP) on innovation activity using an unbalanced panel of nine countries and 12 2-digit manufacturing industries covering the period 1987-2000. Their results suggest that the SMP's product market reforms led to an increase in product market competition which was measured by a reduction in average profitability. Moreover, increased competition led to an increase in $R \& D$ intensity in manufacturing industries. Increased $R \& D$ intensity translated into faster total factor productivity (TFP) growth. The authors indicated that reforms that put pressure on profitability are likely to lead to increased innovation.

Fernandes (2009) examined the effects of increased import competition to product quality upgrading using Chilean manufacturing plant data. The results showed a positive and significant effect from import competition on product level product quality upgrading. The author suggested that increased exposure to import competition, including from China and India, may be beneficial because it encourages producers to focus on offering upgraded and differentiated products, rather than "mundane" labor intensive,ones.

Bloom, Draca, and Van Reenen (2010) examined the impact of Chinese import competition on patenting, IT, R\&D and TFP in 12 EU countries using a panel dataset for the period 1996-2007. The key results are: first, Chinese import competition increases innovation and TFP within surviving firms. Firms facing higher levels of import competition from China create more patents, spend more on $R \& D$, raise their IT intensity and TFP. Secondly, Chinese import competition reduces employment and survival probabilities in low-tech firms, and these firms' TFP declines and they exit much more rapidly than high-tech firms in response to Chinese competition. The authors noted that the results suggest that increased import competition from China has caused a significant technological upgrading in European firms through faster diffusion and innovation. The policy implication is that reducing import barriers against low wage countries like China can bring about welfare gains through technical change. 


\section{Description Of Methodology And Data}

\subsection{Overall Framework}

The foregoing review highlights three important effects of trade liberalization: trade reforms increase competition, trade reforms have positive effects on innovation, and trade reforms lead to the selection of the most productive firms. Trade liberalization thus has pro-competitive effects and as Bhagwati (1968) wrote, it is seen as a powerful and administratively simple way to enhance competition Krugman and Helpman (1989) further noted that international trade increases competition. With trade liberalization, imports can discipline the market by forcing domestic firms to lower their prices and behave competitively. Based on a comprehensive review of empirical studies of firmand plant-level liberalization episodes in various countries, Erdem and Tybout (2003) concluded that mark-ups decline with import competition.

Through the competition channel, trade liberalization also has innovation effects. Newer studies by Fernandes and Bloom, Draca and Van Reenenhave shown some evidence of the positive impact of trade liberalization on innovation. Economic profits or rents can serve as rewards for entrepreneurship and encourage innovation. An increase in competition may increase incentives for incumbent firms to adopt more or to innovate in order to prevent an erosion of their market position. Note, however, that increased competition may also reduce the incentive or reward for innovation or entry and may discourage these activities.

Through the competition channel, trade liberalization also leads to selection effects. As trade liberalization squeezes price cost margins, some intra-plant efficiency gains are made, and additional efficiency gains are induced due to the closure of weak plants. In the presence of within-industry firm heterogeneity, trade liberalization may lead to improved productivity through the exit of inefficient firms and the reshuffling of resources and outputs from less to more efficient firms. Melitz (2003) points out that trade opening may induce a market share reallocation towards more efficient firms and generate an aggregate productivity gain, without any change at the firm level ${ }^{5}$. As

\footnotetext{
${ }^{5}$ The channel through which selection happens is the labor market; trade liberalization increases labor demand, these bids up wages and the cost of production forcing least productive firms to exit the market.
} 
Pavcnik, Topalova, and Tybout showed; trade liberalization induces the least productive firms to exit the market and the most productive non-exporters to become exporters.

Impulliti and Licandro $(2009,2010)^{6}$ introduced a framework that attempts to link together these three effects of trade liberalization. Basically, trade affects both firm selection and innovation through the competition channel. Trade liberalization leads to an increase in the number of firms in the domestic market raising product market competition and lowering the markup rate. The selection effect of trade operates through endogenous markups resulting from oligopolistic competition ${ }^{7}$ among firms. The reduction in the markup rate (or increase in competition) due to trade liberalization reduces profits, raises the productivity threshold above which firms can profitably produce and forces the less productive firms out of the market. Resources are reallocated from exiting firms to the higher productivity surviving firms which innovate at a faster pace.

Given the relationship between trade liberalization and innovation operating through the competition channel, the impact of trade liberalization on innovation is examined through a two-stage approach where competition is endogenous. The same framework was used by Griffith, Harrison, and Simpson (2006) to address the endogeneity of competition in analyzing the relationship between product market reform and innovation in the EU. The following basic econometric model is tested:

Competition function

$$
\text { Competition }_{i j t=} \mathrm{f}\left(\text { Trade }_{j t}, \mathrm{Z}_{i j t}\right)
$$

Innovation function

$$
\text { Innovation }_{i j t=} g\left(\text { Competition }_{i j t}, \mathrm{Z}_{i j t}\right)
$$

Where $i$ indexes firms, $j$ industries and $t$ years. Equation (1) describes the relationship between trade reforms and competition while equation (2) characterizes the relationship between innovation and competition and links trade reforms with innovation through

\footnotetext{
${ }^{6}$ Both are preliminary and incomplete draft versions.

${ }^{7}$ In Melitz (2003), the model assumes monopolistic competition.
} 
competition. $\mathrm{Z}$ is a vector of control variables that may affect the firm's innovation efforts.

Following Aghion et al. (2002), the price cost margin is used as an indicator of product market competition, while research and development expenditures are used as a proxy for innovation. The authors noted that the price cost margin has several advantages over other indicators such as market shares, the Herfindahl index, or the concentration index. These measures require a definition of both the geographic and product boundaries of the market in which the firm operates. This becomes important particularly for firms that operate in international markets, so that traditional market concentration measures could be extremely misleading.

The specific competition and innovation functions are described by equations (3) and (4) below:

$\mathrm{PCM}_{\mathrm{ijt}}=\beta_{0}$ Tariff $_{\mathrm{jt}}+\beta_{1}$ TGap $_{\mathrm{ijt}}+\beta_{2}$ Age $_{\mathrm{ijt}}+\beta_{3} \operatorname{Size}_{\mathrm{ijt}}+\beta_{4}$ Time $+\beta_{5}$ Ind $+\varepsilon_{\mathrm{ijt}}$

equation (3)

$\mathrm{RD}_{\mathrm{ijt}}=\alpha_{0} \mathrm{PCM}_{\mathrm{ijt}}+\alpha_{1} \mathrm{TGap}_{\mathrm{ijt}}+\alpha_{2} \mathrm{Age}_{\mathrm{ijt}}+\alpha_{3} \operatorname{Size}_{\mathrm{ijt}}+\alpha_{4}$ Time $+\alpha_{5}$ Ind $+\omega_{\mathrm{ijt}}$

equation (4)

where PCM is price cost margin, Tariff is a trade reform indicator, TGap or technology gap is the distance to the technological frontier and is a measure of efficiency, RD is research and development expenditures, Age and Size are firm characteristics measured by firm age and total number of workers, respectively; Time and Ind are time and industry dummies, and $\varepsilon$ and $\omega$ are error terms. Apart from output tariff, effective protection rate (EPR) will also be used as a trade reform indicator. EPRs represent rates of protection of value added and measure the net protection received by domestic producers from the protection of their outputs and the penalty from the protection of their inputs.

To control for the effects of the selection process on competition and innovation, net entry is also incorporated in the model: 


$$
\begin{aligned}
& \mathrm{PCM}_{\mathrm{ijt}}=\lambda_{0} \text { Tariff }_{\mathrm{jt}}+\lambda_{1} \text { TGap }_{\mathrm{ijt}}+\lambda_{2} \text { Age }_{\mathrm{ijt}}+\lambda_{3} \operatorname{Size}_{\mathrm{ijt}}+\lambda_{4} \text { NetEntry }_{\mathrm{jt}}+\lambda_{5} \text { Time }+\lambda_{6} \text { Ind }+\rho_{\mathrm{ijt}} \\
& \text { equation (3a) } \\
& \mathrm{RD}_{\mathrm{ijt}}=\delta_{0} \mathrm{PCM}_{\mathrm{ijt}}+\delta_{1} \mathrm{TGap}_{\mathrm{ijt}}+\delta_{2} \mathrm{Age}_{\mathrm{ijt}}+\delta_{3} \operatorname{Size}_{\mathrm{ijt}}+\delta_{4} \text { NetEntry }_{\mathrm{ijt}}+\delta_{5} \text { Time }+\delta_{6} \text { Ind }+\gamma_{\mathrm{ijt}} \\
& \text { equation (4a) }
\end{aligned}
$$

A positive relationship is expected between competition (as measured by PCM) and trade liberalization (with Tariff and EPR as indicators). As tariffs or EPRs are lowered, price cost margin or profitability is reduced, which indicates increased competition. This is the main channel through which trade liberalization affects innovation. Hence, the trade indicators (Tariff and EPR) do not directly enter equation (4).

A negative relationship is expected between PCM (measure of competition) and RD (measure of innovation). As price cost margin or profitability is reduced due to trade reforms, competition increases raising the productivity threshold above which firms can profitably produce. This forces less productive firms out of the market. Resources are reallocated from exiting firms to the higher productivity surviving firms which innovate at a faster pace.

The price cost margin (PCM) or Lerner index is an indicator of the level of competition or degree of monopoly power of firms in industries. It is often used as an indicator of the strength of competition in the market. In theory, it is defined as price minus marginal cost over price and reflects the degree of monopoly power measured by the mark-up pricing above marginal costs (see Appendix 1). It should be noted that high PCMs are not necessarily an indication of bad market performance or that a firm is less competitive. While a high PCM implies market power, it could also indicate high firm efficiency. If these high mark-ups or margins are the result of internal efficiency improving measures or represent gains from product innovation or techniques that a firm employs, then the firm is still considered competitive.

The empirical measurement of PCM is difficult since marginal costs are not directly observable and are quite hard to estimate. Indirect measures have been developed based on accounting data, with average variable costs acting as proxy for marginal costs. Critiques noted that measured in this manner, PCM omits capital costs and becomes a poor indicator of excess profits. 
Aghion et al. (ibid) used operating profits net of depreciation and provisions less the financial cost of capital. This is given by the following:

$$
\mathrm{B}=\frac{\text { Operating profits }- \text { Financial cost of capital }}{\text { Sales }}
$$

where Financial cost of capital is defined as[capital cost $*$ capital stock]. They assumed the cost of capital to be 0.085 for all firms and time periods while capital stock is measured using the perpetual inventory method. Measured this way, it is more like the ratio of price less average cost to price. Note that in 1988, Hall developed an alternative way to measure mark-ups from the production function of firms. Using the properties of the Solow residual under perfect competition, Hall derived an empirical specification that allows the retrieval of industry wide mark-ups (measured by price/marginal costs). Comparing the econometrically estimated PCMs with calculated accounting margins, Siotis (2003) found that overall, the accounting margins approach yields reasonable and precise estimates indicating that accounting based PCM measures may not be as flawed as previously thought, at least when the sample size is large both within the sample and over time.

In this paper, the PCM is defined as:

\footnotetext{
$\mathrm{B}=\frac{\text { Total revenue }- \text { Compensation-Total cost-Financial cost of capital }}{\text { Total revenue }} \quad$ equation (6)

Total $\cos$ ts $=$ Raw materials + Fuel + Electricity + Depreciation + Other cos ts

Financial cos t of capital $=[$ Index of investment goods $*$ Re al int erest rate $] *$ Book value of assets
}

where the implicit price index for gross domestic capital formation is used as a price index of investment goods while the 180-day Treasury Bill interest rate less inflation is used as measure of real interest rate.

Aghion et al. (ibid) measure the technology gap between firms within an industry as the proportional distance a firm is from the technological frontier. In this paper, this is given by the difference between the log total factor productivity (TFP) of the most productive firm in a given industry and $\log$ TFP of each firm in the industry. 
Domestic firms are differentiated depending on the trade orientation of their industry sector. Firms in a traded sector are more exposed to foreign competition than firms in a non-traded sector. Based on the sector's import penetration ratio, and export intensity ratio calculated from the year 2000 Input-Output Table, each industry sector is classified into traded or non-traded. A sector is classified as non-traded if export and import ratios are zero or less than $1 \%$. This includes manufacturing sub-sectors such as slaughtering and meat packing, ice cream, mineral water, and custom tailoring and dressmaking.

A traded sector is categorized into three: purely importable, purely exportable, or mixed. A purely exportable sector is characterized by zero or minimal imports and substantial exports or an export ratio of at least 10\%. Examples are tobacco leaf fluecuring, articles made of native materials, wood carvings, fish drying, knitted hosiery, crude coconut oil, rattan furniture, and jewelry.A purely importable sector is characterized by minimal exports and significant imports or an import ratio of at least $10 \%$. Examples are meat and meat products, coffee roasting and processing, butter and cheese, animal feeds, starch and starch products and manufacture and assembly of motor vehicles. A mixed sector has substantial imports and exports such as motor vehicle parts and components, semi-conductor, parts and supplies for radio, TV, communication, appliances and house wares, garments, carpets and rugs, furniture, along with sugar, glass, chemicals, cigarette, soap and detergents, iron and steel and drugs and medicines. Notice that a lot of the products under both the mixed and purely importable sectors are also among the products with tariff peaks ${ }^{8}$. Moreover, aside from tariff protection, certain products under these sectors also received additional protection through safeguard measures that are imposed on importations of cement, glass, chemicals, and ceramic tiles.

\footnotetext{
${ }^{8}$ Tariff peaks refer to tariffs that are greater than three times the mean tariff. The sectors with tariff peaks were sugarcane, sugar milling and refining, palay, corn, rice and corn milling, vegetables such as onions, garlic, and cabbage, roots and tubers, hogs, cattle and other livestock, chicken, other poultry and poultry products, slaughtering and meat packing, coffee roasting and processing, meat and meat processing, canning and preserving fruits and vegetables, manufacture of starch and starch products, manufacture of bakery products excluding noodles, manufacture of animal feeds, miscellaneous food products, manufacture of drugs and medicines, manufacture of chemical products, and manufacture and assembly of motor vehicles.
} 


\subsection{Data}

The paper uses the firm level panel data created in the first Micro Data Project of the Economic Research Institute for ASEAN and East Asia (ERIA). ${ }^{9}$ The dataset consists of firm level information on revenues, employment, compensation, physical capital, $R \& D$ expenditures, and production costs from the Annual Survey and Census of Establishments of the National Statistics Office (NSO). The firm-level panel dataset built covered the period 1996 to 2006, with three missing years (1999, 2001, and 2004). The years 2000 and 2006 are both census years while the remaining six years are surveys.

The panel dataset is unbalanced and covers all firms with two or more overlapping years during the period 1996-2006. Firms with missing zero or negative values for the variables listed above as well as firms with duplicates were dropped. Firms with missing research and development expenditures and those with less than 10 workers were also excluded. Firm exit is indicated by firms that are no longer included in the 2006 census as well as those whose 2-digit PSIC codes have changed. Firm entry is defined based on the firm's year of establishment or year when it started operating. Net entry by PSIC code is calculated as firm entry less exit. Firm age is calculated based on the firm's year of establishment or year when it started operating. The panel dataset is unbalanced with a total of 8,296 observations. Table 12 presents a summary of the data along with the calculated price cost margins and financial cost of capital.

\footnotetext{
${ }^{9}$ The National Statistics Office provided excellent assistance in building the panel dataset.
} 
Table 12: Summary Statistics

\begin{tabular}{lccccc}
\hline \multicolumn{1}{c}{ Variable } & Obs & Mean & Std. Dev. & Min & Max \\
\hline \hline Total revenue (in million pesos) & 8296 & 736 & 5200 & 0.065 & 233000 \\
Compensation (in million pesos) & 8296 & 43 & 141 & 0 & 2640 \\
Total costs (in million pesos) & 8296 & 594 & 4510 & 0.026 & 203000 \\
Book value of fixed assets (in million pesos) & 8296 & 180 & 1000 & 0 & 47600 \\
Capital cost & 8296 & 0.07 & 0.059 & 0.03 & 0.219 \\
Financial cost of capital (in million pesos) & 8296 & 15 & 102 & 0 & 5750 \\
Price cost margin & 8296 & 0.053 & 0.259 & -6.086 & 0.96 \\
R\&D expenditure share (as \% of value added) & 8296 & 0.005 & 0.068 & 0 & 5.373 \\
Age of firm (in years) & 8263 & 17 & 14 & 0 & 100 \\
Total number of workers & 8296 & 264 & 703 & 10 & 14647 \\
TFP Gap & 8296 & 0.371 & 0.146 & 0 & 1.054 \\
Tariff (in percent) & 8296 & 9.087 & 6.309 & 1.073 & 60 \\
Net entry & 8296 & -3 & 6.9 & -52 & 6 \\
\hline
\end{tabular}

Tariff rates by manufacturing sub-sector were obtained from the Philippine Tariff Commission. The tariff rates are originally coded based on Harmonized System (HS) codes. These were converted into the Philippine System of Industry Classification (PSIC) code to be consistent with the firm level data. Effective protection rates (EPRs were sourced from studies by Manasan and Pineda (1999) for the 1990s and Aldaba (2005) for EPRs in the more recent period.

The TFP Gap indicator was calculated based on the total factor productivity (TFP) estimates obtained from an earlier ERIA study by Aldaba (2010). TFP is defined as the residual of a Cobb-Douglas production function and is estimated using the methodology of Levinsohn and Petrin (2003). In estimating the production function, data on value added (output less cost of materials and energy) and two factors of production, labor and capital, were used. Fuel and electricity data were employed as proxy for productivity shocks. ${ }^{10} \mathrm{~A}$ production function was estimated for 11 industry-sectors. The estimates of firm $i$ 's TFP is obtained by subtracting firm $i$ 's predicted $y$ (or log of output) from its actual $y$ at time t. To make the estimated TFP comparable across industry-

\footnotetext{
${ }^{10}$ To address the simultaneity problem in input choice when estimating the production function by ordinary least squares (OLS), a semi-parametric estimator with an instrument to control for unobserved productivity shocks is applied. For this instrument, Olley and Pakes (1996) use investment while Levinsohn and Petrin (2003) suggest the use of intermediate inputs.
} 
sectors, a productivity index is created. The TFP Gap is given by the difference between the TFP index of the most productive firm in a given industry $j$ at year $t$ and TFP index of each firm $i$ in the industry $j$ at year $t$.

Table 13 presents a descriptive summary of the variables by industry orientation: non-traded (e.g. slaughtering, mineral water, dressmaking), purely importable (e.g meat processing, coffee roasting), purely exportable (e.g. tobacco leaf flue-curing, products made of native materials, fish drying), and mixed sector (e.g. motor vehicles, semiconductors, garments). In terms of R\&D spending (as a percentage of value added), the mixed sector registered the highest ratio at $0.6 \%$, closely followed by the purely importable sector at $0.5 \%$. The purely exportable sector has an average ratio of $0.3 \%$ while the lowest ratio is posted by the non-traded sector at around $0.2 \%$. The purely importable sector has the highest price cost margin at $9.2 \%$ followed by the purely exportable sector at $5.5 \%$ and the mixed sector at $5 \%$. The lowest price cost margin is observed in the non-traded sector with an average PCM at 3.7\%. The mixed sector has the largest average number of workers at 291 followed by the purely importable sector at 209 workers. Average firm age is about 16.3 years in the mixed sector and 18.7 years in the purely importable sector. Average output tariffs are highest in the purely importable sector at $13.4 \%$ followed by the non-traded sector at $9.3 \%$. The lowest output tariff is in the mixed sector at 8.6\%. Average EPRs for all sectors range from 10 to $13.7 \%$.

Table 13: Summary Statistics by Trade Orientation

\begin{tabular}{lcccccccc}
\hline \multirow{2}{*}{ Variable } & \multicolumn{2}{c}{ Non-traded } & \multicolumn{2}{c}{ Purely Importable } & \multicolumn{2}{c}{ Purely exportable } & \multicolumn{2}{c}{ Mixed sector } \\
\cline { 2 - 9 } & Obs & Mean & Obs & Mean & Obs & Mean & Obs & Mean \\
\hline $\begin{array}{l}\text { R\&D expenditure share } \\
\text { (as \% of value added) }\end{array}$ & 377 & 0.0018 & 775 & 0.0045 & 628 & 0.0026 & 6516 & 0.0055 \\
PCM & 377 & 0.0372 & 775 & 0.092 & 628 & 0.0548 & 6516 & 0.0495 \\
Total workers & 377 & 174.082 & 775 & 209.703 & 628 & 108.804 & 6516 & 291.127 \\
Age & 373 & 15.3995 & 771 & 18.6887 & 624 & 18.5016 & 6495 & 16.315 \\
TFP gap & 377 & 0.3859 & 775 & 0.3551 & 628 & 0.3508 & 6516 & 0.374 \\
Tariff & 377 & 9.2912 & 775 & 13.3604 & 628 & 8.9374 & 6516 & 8.5812 \\
EPR & 377 & 12.0489 & 775 & 10.0601 & 628 & 13.6641 & 6516 & 13.7386 \\
\hline
\end{tabular}


Table 14 presents the yearly exit and entry rates. Exit rates increased from $6 \%$ in 1998 to about $22 \%$ in 2000 and $32 \%$ in 2001 but dropped to $26 \%$ in 2003 and further to $13 \%$ in 2005 . Entry rates are low and declined continuously from 5\% in 1998 to $1 \%$ in 2003 and to less than $1 \%$ in 2005 and 2009.

Table 14: Entry and Exit Rates, 1996-2006

\begin{tabular}{cccc}
\hline Year & Exit Rate & Entry Rate & Total Number of Firms \\
\hline 1996 & & & \\
1997 & & & \\
1998 & 6.14 & 5.05 & 277 \\
2000 & 21.96 & 1.63 & 551 \\
2001 & 31.71 & & 1009 \\
2003 & 26.14 & 1 & 903 \\
2005 & 13.05 & 0.24 & 1226 \\
2006 & & 0.09 & 4330 \\
\hline
\end{tabular}

\section{Analysis Of Results}

To examine the impact on innovation of the increased competitive pressure arising from trade reforms, a two-stage approach is applied as specified in equations (3) and (4). The profitability level measured by PCM is the main channel through which trade liberalization affects innovation. PCM and RD are simultaneously determined.

The model is estimated using two methods. First, a two-stage instrumental variables (IV) technique is applied. Equation (3) is the first stage in the IV estimation of the second stage given by equation (4).PCM and RD are estimated by instrumental variables where Tariff is the excluded instrument. Two estimators, fixed effects (FE) and random effects (RE) are used. The Hausman test is used to decide between FE and RE.

Second, a Tobit estimation method is also applied where observations on RD are censored at 0 . Note that RD observations contain either zeroes for firms that do not engage in innovation or a positive value for those that decided to innovate. 


\subsection{All Manufacturing: No Entry and Exit Indicators}

Table 15.1 presents the results of the first stage of the IV estimation which evaluates the degree of correlation between trade reforms, as measured by Tariff, and the endogenous regressor, PCM, which is our measure of profitability. The first stage regression results suggest that the excluded instrument Tariff is highly correlated with PCM based on both the FE and RE methods. The coefficient on Tariff is positive and highly significant indicating that trade reforms have a strong positive impact on the level of profitability. The results also show a negative association between TFP Gap and profitability. The coefficient on TFP Gap is negative and highly significant in both FE and RE methods. This indicates that firms that are farther from a technological frontier (less productive firms) have lower profitability than efficient firms which tend to have higher profitability.

Table 15.1: First Stage IV Results: FE and RE

\section{ALL MANUFACTURING}

\begin{tabular}{|c|c|c|c|c|}
\hline \multirow{2}{*}{ PCM } & \multicolumn{2}{|c|}{ Tariff } & \multicolumn{2}{|c|}{ EPR } \\
\hline & (1) $\mathrm{FE}$ & (2) RE & (1) $\mathrm{FE}$ & (2) RE \\
\hline \multirow[t]{2}{*}{ Age } & 0.00031 & $-0.000458^{*}$ & -0.0039674 & $-0.0008581^{*}$ \\
\hline & 0.0026855 & 0.0002743 & 0.0022206 & 0.000539 \\
\hline \multirow[t]{2}{*}{ Total workers } & -0.00001 & $-0.000028 * * *$ & $-8.15 \mathrm{E}-06^{*}$ & $-0.0000241 * * *$ \\
\hline & 0.0000128 & 0.0000054 & 0.0000128 & $6.94 \mathrm{E}-06$ \\
\hline \multirow[t]{2}{*}{ TFP Gap } & $-2.54176^{* * *}$ & $-1.483633 * * *$ & -2.557112 & $-2.08648 * * *$ \\
\hline & 0.1052527 & 0.04587 & 0.1052544 & 0.0568845 \\
\hline \multirow[t]{2}{*}{ Trade } & $0.0069049 * * *$ & $0.002489 * * *$ & 0.0006741 & 0.0004895 \\
\hline & 0.0022272 & 0.0007028 & 0.0004289 & 0.0002319 \\
\hline \multirow[t]{2}{*}{ Constant } & $1.096718 * * *$ & $0.5535773 * * *$ & 1.254195 & \\
\hline & 0.1022577 & 0.0254748 & 0.0889347 & \\
\hline Year Dummies & $\mathrm{Y}$ & $\mathrm{Y}$ & $\mathrm{Y}$ & $\mathrm{Y}$ \\
\hline Industry Dummies & $\mathrm{Y}$ & $\mathrm{Y}$ & $\mathrm{Y}$ & $\mathrm{Y}$ \\
\hline F-Statistic & 1.65 & & 1.65 & \\
\hline Prob $>$ F & 0 & & 0 & \\
\hline Observations & 8263 & 8263 & 8263 & 8263 \\
\hline R-squared & 0.0672 & & & \\
\hline \multicolumn{5}{|l|}{ Hausman Test } \\
\hline Chi2 & 45.22 & & & 8.27 \\
\hline Prob>chi2 & 0.0001 & & & 0.9605 \\
\hline
\end{tabular}


Using EPR as a trade indicator, the random effects method shows that the coefficient on EPR is positive but not significant. The coefficient on total workers is negative and highly significant. The coefficient on TFP Gap is also negative and highly significant while the coefficient on age is negative and significantly different from zero.

Table 15.2 presents the results of the second stage IV estimation, which looks at the relationship between profitability and innovation where $\mathrm{RD}$ is the dependent variable. The FE results based on Tariff as trade indicator show a significant negative relationship between PCM and RD which indicates that reduced profitability (suggesting high competition) due to trade reform is associated with increased RD. The RE results show the same negative relationship between PCM and RD, but not at a significant level. The coefficient on TFP Gap is negative in both FE and RE methods but is insignificant.

Table 15.2: Second Stage IV Results: FE and RE

\begin{tabular}{|c|c|c|c|c|}
\hline \multirow{2}{*}{ RD } & \multicolumn{2}{|c|}{ Tariff } & \multicolumn{2}{|c|}{ EPR } \\
\hline & (1) FE & (2) $\mathrm{RE}$ & (1) FE & (2) RE \\
\hline \multirow[t]{2}{*}{ PCM } & $-0.114983^{*}$ & -0.095598 & -0.074743 & -0.111575 \\
\hline & -0.0704618 & -0.0776039 & -0.129896 & -0.111468 \\
\hline \multirow[t]{2}{*}{ Age } & -0.00044 & 0.0001051 & -0.000256 & 0.0000963 \\
\hline & -0.0005744 & -0.000084 & -0.000737 & -0.000158 \\
\hline \multirow[t]{2}{*}{ Total workers } & $-0.00000538 *$ & $-2.25 \mathrm{E}-06$ & $-5.06 \mathrm{E}-06^{*}$ & $-4.56 \mathrm{E}-06$ \\
\hline & -0.00000285 & -0.00000265 & $-2.81 \mathrm{E}-06$ & $-3.16 \mathrm{E}-06$ \\
\hline \multirow[t]{2}{*}{ TFP Gap } & -0.11871 & -0.0520831 & -0.015795 & -0.096095 \\
\hline & -0.1816651 & -0.1146816 & -0.332906 & -0.232484 \\
\hline \multirow[t]{2}{*}{ Constant } & 0.09242 & 0.027075 & 0.0419677 & 0.0494711 \\
\hline & -0.0904484 & -0.0444074 & -0.163868 & -0.095103 \\
\hline Year Dummies & $\mathrm{Y}$ & $\mathrm{Y}$ & $\mathrm{Y}$ & $\mathrm{Y}$ \\
\hline Industry Dummies & $\mathrm{Y}$ & $\mathrm{Y}$ & $\mathrm{Y}$ & $\mathrm{Y}$ \\
\hline F-Statistic & 3.13 & & 3.57 & \\
\hline Prob $>F$ & 0 & & 0 & \\
\hline Observations & 8263 & 8263 & 8263 & 8263 \\
\hline R-squared & 0.0044 & & & \\
\hline \multicolumn{5}{|l|}{ Hausman Test } \\
\hline Chi2 & 45.22 & & & 8.27 \\
\hline Prob>chi2 & 0.0001 & & & 0.9605 \\
\hline
\end{tabular}


Using EPR as trade indicator, the random effects method shows that none of the explanatory variables is significant. The coefficient on PCM is negative but is insignificant.

To test the appropriateness of RE, a Hausman test was implemented. Using Tariff as trade indicator, the result shows a rejection of the null hypothesis that the RE estimator is consistent. Using EPR as trade indicator, the result indicates an acceptance of the null hypothesis.

The model is refitted as a Tobit with $\operatorname{lnRD}$ being left censored at zero. The first stage results presented in Table 16.1 show that Tariff has a highly significant positive effect on profitability.TFP Gap has a highly significant negative impact on profitability. Similarly, Total workers also has a highly significant negative impact while Agehas a significant negative effect on profitability. We expect trade reforms to increase the probability that a firm will face more competition and lower profitability. The lower TFP Gap will increase the probability that profitability will be higher. The smaller the firm in terms of numbers of workers and the younger the firm, the higher the probability that profitability will be higher.

Table 16.1: First Stage IV Results: Tobit

ALL MANUFACTURING

\begin{tabular}{|c|c|c|}
\hline PCM & Tariff & EPR \\
\hline \multirow[t]{2}{*}{ Trade } & $0.0012992 * * *$ & 0.0000996 \\
\hline & -0.000547 & -0.0001304 \\
\hline \multirow[t]{2}{*}{ Total workers } & $-0.0000211^{* * *}$ & $-0.000021 * * *$ \\
\hline & -0.00000405 & $-4.05 \mathrm{E}-06$ \\
\hline \multirow[t]{2}{*}{ Age } & $-0.0003406^{*}$ & $-0.0003545^{*}$ \\
\hline & -0.0002017 & -0.0002018 \\
\hline \multirow[t]{2}{*}{ TFP Gap } & $-1.242917 * * *$ & $-1.234866^{* * *}$ \\
\hline & -0.0393622 & -0.039239 \\
\hline \multirow[t]{2}{*}{ Constant } & $0.4478913 * * *$ & 0.4647943 \\
\hline & -0.0196814 & -0.0182534 \\
\hline Year Dummies & $\mathrm{Y}$ & $\mathrm{Y}$ \\
\hline Industry Dummies & $\mathrm{Y}$ & $\mathrm{Y}$ \\
\hline Observations & 8263 & 8263 \\
\hline R-squared & 0.1207 & 0.12 \\
\hline
\end{tabular}


With EPR as trade indicator, the first stage results show that the coefficient on EPR is positive but not significant. The coefficient on TFP is negative and highly significant. The coefficient on total workers is also negative and highly significant. For age, the coefficient is negative and significant.

The second stage Tobitresults are presented in Table 16.2. The results show that with Tariff as trade indicator, PCM has a significant negative effect on $\ln R D$. The lower profitability (suggesting higher competition) will increase the probability that a firm will engage in $R \& D$ activities and will increase its $R \& D$ intensity. The Tobit results also show a highly significant negative effect for Total workers and negative effect for Age. With EPR as trade indicator, none of the explanatory variables is significant. The coefficient on PCM is negative but insignificant.

\section{Table 16.2: Second Stage IV Results: Tobit}

\begin{tabular}{|c|c|c|}
\hline LnRD & Tariff & EPR \\
\hline \multirow[t]{2}{*}{ PCM } & $-10.44935^{*}$ & -10.05107 \\
\hline & -5.906214 & -17.95807 \\
\hline \multirow[t]{2}{*}{ Total workers } & $-0.0005009 * * *$ & -0.0004926 \\
\hline & -0.0001365 & -0.0003815 \\
\hline \multirow[t]{2}{*}{ Age } & $-0.0064991 *$ & -0.0063593 \\
\hline & -0.0035068 & -0.0068841 \\
\hline \multirow[t]{2}{*}{ TFP Gap } & -5.04204 & -4.551069 \\
\hline & -7.30149 & -22.14417 \\
\hline \multirow[t]{2}{*}{ Constant } & -0.5995352 & -0.7849602 \\
\hline & -2.761603 & -8.364468 \\
\hline Year Dummies & $\mathrm{Y}$ & $\mathrm{Y}$ \\
\hline Industry Dummies & $\mathrm{Y}$ & $\mathrm{Y}$ \\
\hline Observations & 8263 & 8263 \\
\hline R-squared & 0.1207 & 0.12 \\
\hline
\end{tabular}

On the whole, using tariffs as trade indicator, the results tend to confirm that trade liberalization may stimulate firms to innovate through competition. For EPR, however, this is not the case. While the correct signs on the coefficient of EPR and PCM are obtained, these are not significant. Regarding the TFP gap, the expected negative relationship is found, however, the result is also not statistically significant. 


\subsection{All Manufacturing: With Entry and Exit Indicators}

Tables 17.1-18.2 show the results with an additional control variable for exit and entry measured by net entry. Using IV, the first stage results indicate a strong positive impact of trade liberalization on competition based on both tariff and EPR as trade indicators. As tariffs (and EPRs) decline, price cost margin or profitability is reduced which indicates increased competition. The coefficient on TFP Gap is negative and highly significant. The coefficient on Net Entry is also negative but insignificant.

Table 17.1: First Stage IV Results: FE and RE

ALL MANUFACTURING

\begin{tabular}{|c|c|c|c|c|}
\hline \multirow{2}{*}{ PCM } & \multicolumn{2}{|c|}{ EPR } & \multicolumn{2}{|c|}{ TARIFF } \\
\hline & (1) FE & (2) $\mathrm{RE}$ & (1) FE & (2) $\mathrm{RE}$ \\
\hline Age & $-0.0039215^{*}$ & $-0.0007018^{*}$ & 0.0003441 & $-0.0004529 *$ \\
\hline standard error & 0.0022208 & 0.0004111 & 0.0026855 & 0.0002718 \\
\hline Total workers & -0.00000818 & $-0.0000282 * * *$ & $-5.38 \mathrm{E}-06$ & $-0.0000279 * * *$ \\
\hline standard error & 0.0000128 & 0.00000648 & 0.0000128 & $5.37 \mathrm{E}-06$ \\
\hline TFP Gap & $-2.557469 * * *$ & $-1.864594 * * *$ & $-2.54216^{* * *}$ & $-1.475161 * * *$ \\
\hline standard error & 0.1052466 & 0.0532788 & 0.1052451 & 0.0456886 \\
\hline Net Entry & -0.0007582 & -0.000508 & -0.0007556 & -0.0001445 \\
\hline standard error & 0.0006247 & 0.0004102 & 0.0006239 & 0.0004494 \\
\hline Trade Indicator & 0.0006674 & $0.000427 * *$ & $0.006884 * * *$ & $0.0024462 * * *$ \\
\hline standard error & 0.0004289 & 0.0002165 & 0.0022271 & 0.0006985 \\
\hline Constant & 1.255121 & & $1.098123 * * *$ & \\
\hline standard error & 0.088931 & & 0.1022564 & \\
\hline Year Dummies & $\mathrm{Y}$ & $\mathrm{Y}$ & $\mathrm{Y}$ & Y \\
\hline Industry Dummies & $\mathrm{Y}$ & $\mathrm{Y}$ & $\mathrm{Y}$ & $\mathrm{Y}$ \\
\hline Observations & 8263 & 8263 & 8263 & 8263 \\
\hline R-squared (overall) & 0.0694 & & 0.0669 & \\
\hline \multicolumn{5}{|l|}{ Hausman Test } \\
\hline Chi2 & & 13.32 & 52.66 & \\
\hline Prob>chi2 & & 0.7145 & 0.0000 & \\
\hline
\end{tabular}

Note: $* 10 \%$ level of significance, $* * 5 \%$ level of significance, $* * * 1 \%$ level of significance. 
Table 17.2: Second Stage IV Results: FE and RE

\begin{tabular}{|c|c|c|c|c|}
\hline \multirow{2}{*}{$\mathbf{R D}$} & \multicolumn{2}{|c|}{ EPR } & \multicolumn{2}{|c|}{ TARIFF } \\
\hline & (1) FE & (2) $\mathrm{RE}$ & (1) FE & (2) RE \\
\hline PCM & -0.0739931 & -0.1189551 & $-0.1148789 *$ & -0.0916575 \\
\hline standard error & 0.1310972 & 0.1272509 & 0.0706754 & 0.0784155 \\
\hline Age & -0.0002561 & 0.0000955 & -0.0004381 & 0.0001054 \\
\hline standard error & 0.0007356 & 0.000136 & 0.000573 & 0.0000833 \\
\hline Total workers & $-0.00000505^{*}$ & -0.00000422 & $-0.00000538 *$ & $-2.09 \mathrm{E}-06$ \\
\hline standard error & 0.00000282 & 0.00000396 & 0.00000285 & $2.65 \mathrm{E}-06$ \\
\hline TFP Gap & -0.0138511 & -0.1017999 & -0.1184321 & -0.0459054 \\
\hline standard error & 0.3360179 & 0.2370014 & 0.1822321 & 0.1152147 \\
\hline Net Entry & 0.0000574 & 0.0000826 & 0.0000259 & 0.0001785 \\
\hline standard error & 0.0171815 & 0.0001225 & 0.0001468 & 0.0001243 \\
\hline Constant & 0.0409574 & 0.0471517 & 0.0922571 & 0.0306018 \\
\hline standard error & 0.1654865 & 0.092097 & 0.0907753 & 0.0469146 \\
\hline Year Dummies & $\mathrm{Y}$ & $\mathrm{Y}$ & $\mathrm{Y}$ & $\mathrm{Y}$ \\
\hline Industry Dummies & $\mathrm{Y}$ & $\mathrm{Y}$ & $\mathrm{Y}$ & $\mathrm{Y}$ \\
\hline Observations & 82633 & 8263 & 8263 & 8263 \\
\hline R-squared (overall) & 0.0047 & 0.0102 & 0.0044 & 0.0118 \\
\hline
\end{tabular}

In the second stage, the results based onthe fixed effects (FE) method withTariff as trade indicator, show some evidence of a positive effect of competition on innovation brought about by trade liberalization. The coefficient on PCM is negative and significant at the $10 \%$ level. The coefficient on Total workers is negative and significant. The coefficient on TFP gap is negative but not statistically significant. In the case of EPR as trade indicator, the random effects (RE) results show that although the coefficient on PCM is negative, it is not significant. It is important to note that the EPRs used are based only on output and input tariff rates and do not take into account the presence of non-tariff barriers, such as import controls and restrictions, which are more binding than tariffs. Although tariff rates are reduced, importation is still limited 
due to the presence of these restrictions. This may be one possible explanation of why in most cases, though EPR has the correct sign, it is not significant. ${ }^{11}$

Tables 18.1-18.2 present the results of the first and second stages, respectively, using a Tobit regression.Based on Tariff as trade indicator, trade liberalization has a positive effect on innovation through competition. The results show a positive relationship between tariff and PCM and a negative relationship between PCM (measure of competition) and RD (measure of innovation).

\section{Table 18.1: First Stage TOBIT}

\section{ALL MANUFACTURING}

\begin{tabular}{|c|c|c|}
\hline PCM & EPR & TARIFF \\
\hline Trade Indicator & 0.0000993 & $0.0012991 * * *$ \\
\hline standard error & 0.0001304 & 0.0005476 \\
\hline Total workers & $-0.000021 * * *$ & $-0.0000211 * * *$ \\
\hline standard error & 0.00000405 & 0.00000405 \\
\hline Age & $-0.0003541 *$ & $-0.0003405^{*}$ \\
\hline standard error & 0.0002018 & 0.0002018 \\
\hline TFP Gap & $-1.234975 * * *$ & $-1.242921 * * *$ \\
\hline standard error & 0.0392628 & 0.0393829 \\
\hline Net Entry & -0.0000404 & -0.00000138 \\
\hline standard error & 0.0004832 & 0.0004833 \\
\hline Constant & $0.4647379 * * *$ & $0.4478903 * * *$ \\
\hline standard error & 0.0182669 & 0.0196862 \\
\hline Year Dummies & $\mathrm{Y}$ & $\mathrm{Y}$ \\
\hline Industry Dummies & $\mathrm{Y}$ & $\mathrm{Y}$ \\
\hline Observations & 8263 & 8263 \\
\hline Adj R-squared & 0.118 & 0.1186 \\
\hline
\end{tabular}

\footnotetext{
${ }^{11}$ Import ratios were also calculated as an alternative trade indicator. However, the inconsistencies in using matched aggregated import data at the industry level with the survey and census data prevented us from using them.
} 
Table 18.2: Second Stage TOBIT

\begin{tabular}{lcc}
\hline \multicolumn{1}{c}{ LnRD } & EPR & TARIFF \\
\hline \hline PCM & -11.70061 & $-11.17755^{*}$ \\
standard error & 19.68247 & 6.144492 \\
Total workers & -0.0005295 & $-0.0005185^{* * *}$ \\
standard error & 0.0004182 & 0.000142 \\
Age & -0.0067569 & $-0.0065736^{*}$ \\
standard error & 0.0075315 & 0.0036446 \\
TFP Gap & -6.638679 & -5.993806 \\
standard error & 24.27343 & 7.596961 \\
Net Entry & $-0.0188524 * *$ & $-0.0188251 * * *$ \\
standard error & 0.0073079 & 0.0070451 \\
Constant & -0.0445921 & -0.2880717 \\
standard error & 9.166121 & 2.872541 \\
Year Dummies & $\mathrm{Y}$ & $\mathrm{Y}$ \\
Industry Dummies & $\mathrm{Y}$ & $\mathrm{Y}$ \\
Observations & 8263 & 8263 \\
R-squared & & \\
\hline Note: $* 10 \%$ level of significance, $* 5 \%$ level of significance, ***1\% level of significance.
\end{tabular}

In the first stage, the coefficient on TFP gap is negative and highly significant. Similarly, the coefficient on Total Workers is negative and highly significant. The coefficient on Net Entry is negative but is insignificant. In the second stage, the coefficient on Net Entry is negative and highly significant indicating that higher net exit will increase the probability that surviving firms will engage in $R \& D$ activities. Note that as tariffs decline, price cost margin or profitability is reduced, competition increases and less efficient firms are forced out of the market. The coefficient on Age is negative and significant and similarly, the coefficient on Total Workers is negative and highly significant. Based on EPR as trade indicator, the evidence that trade liberalization leads to innovation is relatively weaker. The coefficient on PCM is negative, but not significant.

\subsection{Manufacturing by Trade Orientation: No Entry and Exit Indicators}

The model is next tested using the different manufacturing sectors classified based on their trade orientation: non-traded, purely importable, purely exportable, and mixed 
sector. Two regressions methods are applied, IV and Tobit. For IV, two estimation techniques are applied: FE and RE.Two trade indicators are used, output tariffs and effective protection rates.

Tables 19.1-20.2 summarize the key results for the mixed sectors.Using IV regression and Tariff as trade indicator, some evidence of a positive effect of trade liberalization on innovation is found. The coefficient on Tariff is positive and highly significant while the coefficient on PCM is negative and significant. Using EPR as trade indicator, the coefficient is positive and highly significant, but for PCM, while the coefficient is negative it is not significant.

Table 19.1: First Stage IV Results: FE and RE

\section{MIXED SECTOR}

\begin{tabular}{|c|c|c|c|c|}
\hline \multirow{2}{*}{ PCM } & \multicolumn{2}{|c|}{ EPR } & \multicolumn{2}{|c|}{ TARIFF } \\
\hline & (1) FE & (2) $\mathrm{RE}$ & (1) FE & (2) RE \\
\hline \multirow[t]{2}{*}{ Age } & -0.002196 & -0.0007068 & 0.000307 & -0.0006029 \\
\hline & -0.0025562 & -0.0004806 & -0.0032214 & -0.0004183 \\
\hline \multirow[t]{2}{*}{ Total workers } & $-9.02 \mathrm{E}-06$ & $-.0000277 * * *$ & $-9.32 \mathrm{E}-06$ & $-.0000288 * * *$ \\
\hline & -0.0000131 & $-6.69 \mathrm{E}-06$ & -0.0000131 & $-6.37 \mathrm{E}-06$ \\
\hline \multirow[t]{2}{*}{ TFP Gap } & $-2.663347 * * *$ & $-1.983007 * * *$ & $-2.664046^{* * *}$ & $-1.855282 * * *$ \\
\hline & -0.1171964 & -0.061406 & -0.1172395 & -0.0592093 \\
\hline \multirow[t]{2}{*}{ Trade Indicator } & $.0024892 * * *$ & $.0017411 * * *$ & $.0075801 * *$ & $.006108 * * *$ \\
\hline & -0.0009776 & -0.000455 & -0.0034387 & -0.0014744 \\
\hline \multirow[t]{2}{*}{ Constant } & $.9566725 * * *$ & & $.8702728 * * *$ & \\
\hline & -0.1404109 & & -0.1532073 & \\
\hline Year Dummies & $\mathrm{Y}$ & $\mathrm{Y}$ & $\mathrm{Y}$ & $\mathrm{Y}$ \\
\hline Industry Dummies & $\mathrm{Y}$ & $\mathrm{Y}$ & $\mathrm{Y}$ & $\mathrm{Y}$ \\
\hline Observations & 6495 & 6495 & 6495 & 6495 \\
\hline R-squared (overall) & 0.0723 & & 0.0736 & \\
\hline \multicolumn{5}{|l|}{ Hausman Test } \\
\hline Chi2 & & 9.67 & & 9.23 \\
\hline Prob $>$ chi2 & & 0.9169 & & 0.9329 \\
\hline
\end{tabular}


Table 19.2: Second Stage IV Results: FE and RE

MIXED SECTOR

\begin{tabular}{lcccc}
\hline \multirow{2}{*}{ RD } & \multicolumn{2}{c}{ EPR } & (1) FE & (2) RE \\
\cline { 2 - 5 } PCM & $\mathbf{( 1 )} \mathbf{~ F E}$ & $\mathbf{( 2 )} \mathbf{R E}$ & -0.1351851 & $-.1295984^{*}$ \\
& -0.0552967 & -0.0906546 & -0.107184 & -0.0682428 \\
Age & -0.0833932 & -0.0678799 & -0.0004435 & 0.0001018 \\
Total workers & -0.0000902 & 0.0001219 & -0.0007396 & -0.0001255 \\
& -0.0006294 & -0.0001337 & $-5.67 \mathrm{e}-06 *$ & $-3.80 \mathrm{E}-06$ \\
TFP Gap & $-4.91 \mathrm{e}-06^{*}$ & $-3.09 \mathrm{E}-06$ & $-3.26 \mathrm{E}-06$ & $-2.70 \mathrm{E}-06$ \\
& $-2.89 \mathrm{E}-06$ & $-2.58 \mathrm{E}-06$ & -0.1875423 & -0.1114657 \\
Constant & 0.0258156 & -0.0453125 & -0.2875925 & -0.126285 \\
& -0.2241031 & -0.1348436 & 0.0858808 & 0.0527683 \\
Year Dummies & 0.0048743 & 0.0256419 & -0.1135132 & -0.0512104 \\
Industry Dummies & -0.0895349 & -0.0546182 & $\mathrm{Y}$ & $\mathrm{Y}$ \\
Observations & $\mathrm{Y}$ & $\mathrm{Y}$ & $\mathrm{Y}$ & $\mathrm{Y}$ \\
R-squared (overall) & $\mathrm{Y}$ & $\mathrm{Y}$ & 6495 & 6495 \\
\hline
\end{tabular}

The same results are obtained in the Tobit regression; both EPR and tariff have the correct positive signs which are highly significant; however, while the coefficient on PCM is negative as expected, it is not significant. The results also show a highly significant negative relationship between PCM and TFP gap and a highly significant negative relationship between number of workers and R\&D. 
Table 20.1: First Stage IV Results: Tobit MIXED SECTOR

\begin{tabular}{lcc}
\hline \multicolumn{1}{c}{ PCM } & (1) TARIFF & (2) EPR \\
\hline \hline Age & $-.0003994 *$ & $-.0003936^{*}$ \\
Total workers & -0.0002435 & -0.0002436 \\
& $-.0000216^{* * *}$ & $-.0000219^{* * *}$ \\
TFP Gap & $-4.33 \mathrm{E}-06$ & $-4.34 \mathrm{E}-06$ \\
& $-1.332122^{* * *}$ & $-1.322314^{* * *}$ \\
Trade Indicator & -0.0474155 & -0.0472372 \\
& $.0030229 * * *$ & $.0005372 *$ \\
Constant & -0.001026 & -0.0002858 \\
& $.4655379 * * *$ & $.5039854 * * *$ \\
Year Dummies & -0.0301794 & -0.0258772 \\
Industry Dummies & $\mathrm{Y}$ & $\mathrm{Y}$ \\
Observations & $\mathrm{Y}$ & $\mathrm{Y}$ \\
Adj R-squared & 6495 & 6495 \\
\hline
\end{tabular}

Table 20.2: Second Stage IV Results: Tobit

\begin{tabular}{|c|c|c|}
\hline LnRD & (1) TARIFF & (2) EPR \\
\hline \multirow[t]{2}{*}{ PCM } & -5.733137 & -8.414397 \\
\hline & -3.639965 & -6.594807 \\
\hline \multirow[t]{2}{*}{ Total workers } & $-.0003721 * * *$ & $-.000431 * * *$ \\
\hline & -0.0000925 & $(.0001546)^{*}$ \\
\hline \multirow[t]{2}{*}{ Age } & $-.0060584 * *$ & -0.0070863 \\
\hline & -0.0029606 & -0.003938 \\
\hline \multirow[t]{2}{*}{ TFP Gap } & 0.9419193 & -2.583998 \\
\hline & -4.813166 & -8.691929 \\
\hline \multirow[t]{2}{*}{ Constant } & $-5.503807 * * *$ & -4.12588 \\
\hline & -1.890225 & -3.403656 \\
\hline Year Dummies & $\mathrm{Y}$ & $\mathrm{Y}$ \\
\hline Industry Dummies & $\mathrm{Y}$ & $\mathrm{Y}$ \\
\hline Observations & 6495 & 6495 \\
\hline
\end{tabular}


For the other remaining sectors- non-traded, purely importable, and purely exportable- the evidence that trade liberalization affects innovation through competition seems to be weak. The general results show that although the coefficient on the trade indicator (EPR or Tariff) is correct, it is not significant. Similarly, the coefficient on PCM has the correct sign but is also not significantly different from zero.

\subsection{Manufacturing by Trade Orientation: With Entry and Exit Indicators}

The next set of results use the same basic model with a control variable for the selection process measured by Net Entry. Tables 21.1 to 22.2 present the results for the mixed sector.With Net Entry as an additional control variable, the results based on Tariff as trade indicator show some evidence of a positive effect of competition on innovation brought about by trade liberalization.

Using IV regression with Tariff as trade indicator, the REfirst stage results show that Tariff and PCM have a positive relationship that is highly significant. TFP and PCM have a highly significant negative relationship indicating that less efficient firms have lower profitability. The coefficient on Total Workers is negative and highly significant. The second stage results show that PCM and R\&D have a significant negative relationship. 
Table 21.1: First Stage IV Results: FE and RE

MIXED SECTOR

\begin{tabular}{|c|c|c|c|c|}
\hline \multirow[b]{2}{*}{ PCM } & \multicolumn{2}{|c|}{ EPR } & \multicolumn{2}{|c|}{ TARIFF } \\
\hline & (1) FE & (2) $\mathrm{RE}$ & (1) FE & (2) RE \\
\hline \multirow[t]{2}{*}{ Age } & -0.0022093 & -0.0006576 & 0.000412 & -0.0005626 \\
\hline & 0.0025548 & 0.00045 & 0.0032198 & 0.0014297 \\
\hline \multirow[t]{2}{*}{ Total workers } & -0.00000916 & $-0.0000285^{* * *}$ & -0.00000945 & $-0.0000292 * * *$ \\
\hline & 0.0000131 & 0.00000654 & 0.0000131 & 0.0003939 \\
\hline \multirow[t]{2}{*}{ TFP Gap } & $-2.663204 * * *$ & $-1.919879 * * *$ & $-2.663662 * * *$ & $-1.793328 * * *$ \\
\hline & 0.1171321 & 0.0603512 & 0.1171664 & 0.00000622 \\
\hline \multirow[t]{2}{*}{ Net Entry } & $-0.0012348^{*}$ & $-0.000747^{*}$ & $-0.0012958^{* *}$ & -0.0005875 \\
\hline & 0.0006493 & 0.000448 & 0.0006495 & 0.0581184 \\
\hline \multirow[t]{2}{*}{ Trade Indicator } & $0.0024525^{* * *}$ & $0.0016159 * * *$ & $0.0077154 * *$ & $0.0057119^{* * *}$ \\
\hline & 0.0009773 & 0.0004418 & 0.0034372 & 0.0004647 \\
\hline \multirow[t]{2}{*}{ Constant } & $0.9578304 * * *$ & $0.734464 * * *$ & $0.8680335^{* * *}$ & \\
\hline & 0.1403352 & 0.0323591 & 0.1531157 & \\
\hline Year Dummies & $\mathrm{Y}$ & $\mathrm{Y}$ & $\mathrm{Y}$ & $\mathrm{Y}$ \\
\hline Industry Dummies & $\mathrm{Y}$ & $\mathrm{Y}$ & $\mathrm{Y}$ & $\mathrm{Y}$ \\
\hline Observations & 6495 & & 6495 & 6495 \\
\hline R-squared (overall) & 0.0723 & & 0.073 & \\
\hline \multicolumn{5}{|l|}{ Hausman Test } \\
\hline Chi2 & & 11.99 & & 11.65 \\
\hline Prob>chi2 & & 0.848 & & 0.821 \\
\hline
\end{tabular}

Table 21.2: Second Stage IV Results: FE and RE

\begin{tabular}{lcccc}
\hline \multirow{2}{*}{ RD } & \multicolumn{2}{c}{ EPR } & \multicolumn{2}{c}{ TARIFF } \\
\cline { 2 - 5 } & $\mathbf{( 1 )} \mathbf{~ F E}$ & $\mathbf{( 2 )} \mathbf{~ R E}$ & $\mathbf{( 1 )} \mathbf{~ F E}$ & $\mathbf{( 2 ) ~ R E}$ \\
\hline \hline PCM & -0.0543989 & -0.0956812 & -0.1348164 & $-0.1336937^{*}$ \\
Age & 0.0846258 & 0.0727616 & 0.1052708 & 0.0724602 \\
& -0.0000874 & 0.0001196 & -0.0004415 & 0.0001007 \\
Total workers & 0.0006315 & 0.0001289 & 0.0007327 & 0.0001213 \\
& $-0.00000489^{*}$ & -0.00000302 & $-0.00000567^{*}$ & -0.00000371 \\
TFP Gap & 0.0000029 & 0.00000274 & 0.00000326 & 0.00000281 \\
& 0.0281981 & -0.0523605 & -0.186552 & -0.1139012 \\
Net Entry & 0.2273521 & 0.139814 & 0.2824784 & 0.1294799 \\
& 0.0000751 & 0.0001017 & -0.0000268 & 0.0001094 \\
& 0.0001747 & 0.0001321 & 0.0002033 & 0.0001416 \\
\hline
\end{tabular}


Table 21.2: (continued) Second Stage IV Results: FE and RE

\begin{tabular}{lcccc}
\hline \multirow{2}{*}{ RD } & \multicolumn{2}{c}{ EPR } & \multicolumn{2}{c}{ TARIFF } \\
\cline { 2 - 5 } & (1) FE & (2) RE & (1) FE & (2) RE \\
\hline \hline Constant & 0.0039449 & 0.0286122 & 0.0855136 & 0.0519422 \\
Year Dummies & 0.0907382 & 0.05666 & 0.1116845 & 0.0506673 \\
Industry Dummies & $\mathrm{Y}$ & $\mathrm{Y}$ & $\mathrm{Y}$ & $\mathrm{Y}$ \\
Observations & $\mathrm{Y}$ & $\mathrm{Y}$ & $\mathrm{Y}$ & $\mathrm{Y}$ \\
R-squared (overall) & 624 & 624 & 6495 & 6495 \\
\hline
\end{tabular}

The Tobit results show that based on Tariff as trade indicator, there is some evidence linking trade liberalization to innovation through competition. In the first stage, a highly significant positive relationship between PCM and Tariff is found. With respect to the control variables, the coefficient on Age is negative and significant while the coefficient on TFP gap is negative and highly significant. The coefficient on Total Workers is negative and highly significant.

Table 22.1: First Stage IV Results: Tobit

MIXED SECTOR

\begin{tabular}{lcc}
\hline \multicolumn{1}{c}{ PCM } & (1) TARIFF & (2) EPR \\
\hline \hline Age & $-0.0004035^{*}$ & $-0.000397^{*}$ \\
Total workers & 0.0002437 & 0.0002438 \\
TFP Gap & $-0.0000216^{* * *}$ & $-0.0000218^{* * *}$ \\
& 0.00000434 & 0.00000434 \\
Trade Indicator & $-1.331775^{* * *}$ & $-1.321962^{* * *}$ \\
& 0.0474237 & 0.047248 \\
Net Entry & $0.0030443^{* * *}$ & $0.0005407^{*}$ \\
Constant & 0.001027 & 0.000286 \\
& 0.0002632 & 0.0002235 \\
Year Dummies & 0.0005458 & 0.0005457 \\
Industry Dummies & $0.4598655^{* * *}$ & $0.4916265^{* * *}$ \\
Observations & 0.0267683 & 0.0235211 \\
Adj R-squared & $\mathrm{Y}$ & $\mathrm{Y}$ \\
\hline & $\mathrm{Y}$ & $\mathrm{Y}$ \\
& 6495 & 6495 \\
& 0.1188 & 0.1181 \\
\hline
\end{tabular}


Table 22.2: Second Stage IV Results: Tobit

\begin{tabular}{|c|c|c|}
\hline LnRD & (1) TARIFF & (2) EPR \\
\hline \multirow[t]{2}{*}{ PCM } & $-6.083573^{*}$ & -8.772339 \\
\hline & 3.682705 & 6.686467 \\
\hline \multirow[t]{2}{*}{ Age } & $-0.0059966^{* *}$ & $-0.0070351^{*}$ \\
\hline & 0.0030161 & 0.0040205 \\
\hline \multirow[t]{2}{*}{ Total workers } & $-0.0003815^{* * *}$ & $-0.0004406^{* * *}$ \\
\hline & 0.0000937 & 0.0001567 \\
\hline \multirow[t]{2}{*}{ TFP Gap } & 0.4578945 & -3.076967 \\
\hline & 4.868762 & 8.810686 \\
\hline \multirow[t]{2}{*}{ Net entry } & $-0.013027 * *$ & $-0.0125073 *$ \\
\hline & 0.0059947 & 0.0070161 \\
\hline \multirow[t]{2}{*}{ Constant } & -2.754255 & -1.409861 \\
\hline & 1.85854 & 3.355992 \\
\hline Year Dummies & $\mathrm{Y}$ & $\mathrm{Y}$ \\
\hline Industry Dummies & $\mathrm{Y}$ & $\mathrm{Y}$ \\
\hline Observations & 6495 & 6495 \\
\hline
\end{tabular}

In the second stage(R\&D equation), the coefficient on PCM is negative and significant. The Net Entry indicator and PCM also have a negative correlation that is significant at the 5\% level which suggests that as more firms exit (presumably the inefficient ones), the remaining or surviving firms tend to engage in $R \& D$ activities. These results tend to show that with a tariff reduction, firm profitability declines which indicates an increase in competition. As competition increases, less productive firms are forced out of the market while the productivity and innovation activities of surviving firms increase. The second stage IV results also show a significant relationship between Age and LnRDand a highly significant negativecorrelation between total workers and LnRD.

For the non-traded, purely importable and purely exportable sectors, the same results obtained earlier were found, indicating the lack of strong evidence that would link trade liberalization with innovation. While the correct signs on the coefficients are obtained in most cases, these are not statistically significant. 


\section{Conclusions and Policy Implications}

\subsection{Summary of Major Findings}

The most recent literature on trade and growth shows that international trade affects firms' innovative activities through increased competition. As Licandro (2010) noted, increasing evidence supports the claim that international trade enhances innovation and productivity growth through an increase in competition. In the Philippines, trade liberalization has been at the core of economic reforms. The increase in competition arising from the removal of barriers to trade has presented both opportunities and challenges to domestic firms to innovate and improve their productivity. This paper has attempted to examine the link between trade liberalization and innovation. What is the impact of the removal of barriers to trade on the firms' innovative activities? Did the increase in competition arising from trade reforms lead to increases in innovation?

Impulliti and Licandro $(2009,2010)$ introduced a framework where trade affects both firm selection and innovation through the competition channel. Given an oligopolistic environment, trade liberalization leads to an increase in the number of firms in the domestic market which raises product market competition and lowers the markup rate. The selection effect of trade operates through endogenous markups resulting from oligopolistic competition among firms. The reduction in the markup rate (or increase in competition) due to trade liberalization reduces profits, increases the productivity threshold above which firms can profitably produce and forces the less productive firms out of the market. Resources are reallocated from exiting firms to the higher productivity surviving firms which innovate at a faster pace.

Without Net Entry indicator, both the IV and Tobit results show that for overall manufacturing industry, trade liberalization affects innovation through competition. In the first stage, Tariff is highly correlated with PCM while in the second stage, a significant relationship between PCM and R\&D is obtained. This suggests that reduced profit (which implies high competition) is associated with increased R\&D. 
Controlling for firm entry and exit, the IV and Tobit results show generally the same findings. With Tariff as trade indicator, trade liberalization has a strong positive impact on competition while competition has a significant effect on R\&D.

Firms have also been grouped based on their trade orientation intensity: nontraded, purely importable, purely exportable, and mixed sector. It is in the latter sector where trade is most intense. In general, the major results again confirm the importance of market competition as the channel through which trade liberalization affects innovation. Selection arising from competition also plays a role. These results are highlighted in the mixed sector which is characterized by substantial imports and exports of products in industries like motor vehicle parts and components, semiconductors, parts and supplies for radio, TV, communication, appliances and house wares, garments, carpets and rugs, furniture, along with sugar, glass, chemicals, cigarette, soap and detergents, iron and steel and drugs and medicines.

Based on IV regression, the key results in the mixed sector show a significant positive effect of trade liberalization on innovation through competition. The same results are obtained in both models with and without the Net Entry indicator. The results tend to show that with a tariff reduction, firm profitability declines which indicates an increase in competition. As competition increases, the productivity threshold in which firms could operate profitably increases, hence less productive firms are forced out of the market while more productive firms are allowed to continue their operations. With competition, the productivity and innovation activities of the surviving firms increase.

The Tobit results show a highly significant positive relationship between PCM and Tariff as well as a significant positive relationship between PCM and EPR. In the first stage, a highly significant positive relationship between PCM and Tariff is found. In the second stage, a significant negative correlation between PCM and LnRD is found. The Net Entry indicator and PCM also have a negative correlation that is significant at the $5 \%$ level.This suggests that as more firms exit (presumably the inefficient ones), the remaining or surviving firms tend to engage in $R \& D$ activities. The results tend to imply that with a tariff reduction firm profitability declines which indicates an increase in competition. As competition increases, less productive firms are forced out of the market while the productivity and innovation activities of surviving firms increase. 


\subsection{Some Policy Recommendations}

Given the crucial role of competition in the relationship between trade liberalization and innovation, it is important for the government to maintain the contestability of markets. Contestability is the essence of effective competition;for as long as markets remain contestable (when entry into a market is easy), we would expect large firms in an oligopolistic environment to act independently, and monopolies to behave in a competitive manner. If entry is easy and costless, the potential threat from imports or from domestic competitors will make incumbent firms behave competitively.

It is important to note that the presence of market imperfections,such as abuse of dominant position and other anti-competitive business practices, along with trade barriers or government regulations, limit market entry and create inefficiencies leading to reduced long-term growth. These weaken competition and prevent structural changes from taking place, resulting in resources being tied to low-productivity industries. Weak competition reduces the pressure on firms to adopt new technology or innovate, resulting in low growth of productivity and a loss of competitiveness.

Philippine experience has shown that after two decades of implementing liberalization and other market-opening policies, competition and productivity growth remained weak not only due to the presence of structural and behavioral barriers to entry, but also to the country's inadequate physical and institutional infrastructure. Due to the fundamental weakness of competition in many major economic sectors, the gains from liberalization remained limited which slowed down the country's economic growth.

The results have a bearing on the possible impact of the government's selective protection policy on competition and innovation. This policy, which was adopted in 2003, increased the tariff rates on selected agriculture and manufacturing products which has led to a sizeable proportion of products with tariff peaks. The paper's findings tend to suggest that an increase in tariffs will increase profitability and reduce competition which would likely result in reduced innovation, holding all else equal. The selective protection policy must thus be reviewed, given its likely negative impact on competition and innovation and taking into account the current low level of R\&D spending and overall innovation activity in the country. 
It is necessary to address the remaining barriers to market entry (and exit) such as selective tariff protection and non-tariff measures in rice, sugar, automotive parts and components and other manufacturing products. The government needs to veer away from protectionist policies and mechanisms that intervene in the market and try to decide and select which firms should survive and which ones would die. In the light of the findings of this paper and the increasing globalization and economic integration that make industries more mobile through production networks and supply chains, the government should focus on designing an overall policy and strategy that would ensure competition, innovation and the productivity growth of firms.Beginning in January 2010, the ASEAN Trade in Goods Agreement (ATIGA) where tariffs were reduced to zero in a substantial number of products has been implemented. Whether this will lead to more competitive markets in the Philippines dependsnot only on the overall trade creation and trade diversion effects of the ASEAN Economic Community (AEC) but also on the government strategy that will be put in place to help our industries face increased competition from imports, and take advantage of opportunities such as bigger export markets and increased foreign direct investment flows. Note also that there are other important determinants of innovation including human capital, infrastructure, and institutional factors that must be closely examined along with their interaction with trade policy reform indicators. 


\section{References}

Aghion, Philippe, Robin Burgess, Stephen Redding and FabrizioZilibotti (2005), 'Entry Liberalization and Inequality in Industrial Performance', Journal of the European Economic Association, Papers and Proceedings, 3(2-3), pp.291-302.

Aghion, P. and Robin Burgess (2003), 'Liberalization and Industrial Performance: Evidence from India and the UK'.

Aghion, P., Nicholas Bloom, Richard Blundell, Rachel Griffith, and Peter Howitt (2002), 'Competition and Innovation: An Inverted U Relationship', Working Paper 9269. Cambridge, MA: National Bureau of Economic Research.

Aghion, P. and Peter Howitt (1999), Endogenous Growth Theory. US: Massachusetts Institute of Technology.

Aldaba, R.(2008), 'Assessing Competition in Philippine Markets', PIDS Discussion Paper 2008-23, Makati City.

Aldaba, R. (2005). 'Policy Reversals, Lobby Groups and Economic Distortions', PIDS Discussion Paper No. 2005-04. Makati City: Philippine Institute for Development Studies.

Aldaba, R. (2010), 'Does Trade Protection Improve Firm Productivity? Evidence from Philippine Micro Data', Paper submitted to ERIA in March 2010.

Bloom, N., MirkoDraca, and J. Van Reenen (2010), 'Trade Induced Technical Change? The Impact of Chinese Imports on Innovation, IT and Productivity'.

Blundell, R., R. Griffith, and J. Van Reenen. (1995), 'Dynamic Count Data Models of Technological Innovation', Economic Journal, 105(429), pp.333-344.

Carlin, Wendy, Mark E. Schaffer and Paul Seabright (2004), 'A Minimum of Rivalry: Evidence from Transition Economies on the Importance of Competition for Innovation and Growth', Berkeley Electronic Press. Contributions to Economic Analysis \& Policy 3(1), pp. 1-42.

Cororaton, C. (1999), 'R\&D Gaps in the Philippines', PIDS Discussion Paper Series No. 99-16, Makati City, Philippines.

Cororaton, C. (2002), 'Technological Innovations in Japan and S\&T Experiences in the Philippines Drawing Policy Lessons for the Philippines', PIDS Research Paper Series No. 2002-04, Makati City, Philippines.

Creusen, H., B. Vroomen, H. van derWiel and F. Kuypers. (2006), 'Dutch Retail Trade On The Rise?: Relation Between Competition, Innovation And Productivity', CPB Document 137, CPB Netherlands Bureau for Economic Policy Analysis.

Domowitz, I., Hubbard \& Petersen (1986), 'The Intertemporal Stability of the Concentration Margins Relationship', Journal of Industrial Economics, 35(1), pp.13-34.

Fernandes, A. and Caroline Paunov (2009), 'Does Tougher Import Competition Foster Product Quality Upgrading?', Policy Research Working Paper no. 4894, Washington D.C: The World Bank. 
Geroski, P. (1990), 'Innovation, Technological Opportunity and Market Structure', Oxford Economic Papers 42, pp.586-602.

Geroski,P. (1995), Market Structure, Corporate Performance and Innovative Activity. Oxford, U.K. : Oxford University Press.

Gilbert, R. (2006), 'Looking for Mr. Schumpeter: Where Are We in the CompetitionInnovation Debate?', Innovation Policy and the Economy, 6, pp.159-215,

Gorodnichenko, Y., Jan Svejnar, and Katherine Terell (2009), 'Globalization and Innovation in Emerging Markets', Policy Research Working Paper 4808, Washington D.C.: The World Bank.

Griffith, R., Rupert Harrison, and Helen Simpson (2006), 'The Link Between Product Market Reform, Innovation and EU Macroeconomic Performance', European Economy Economic Papers 243, Brussels: European Commission.

Griliches, Z. (1992), 'The Search for R\&D Spillovers', Scandinavian Journal of Economics, 94, pp.29-47.

Hall, R. (1988), 'The Relation between Price and Marginal Cost in US Industry', Journal of Political Economy, 96, pp.921-947.

Hopman, C. and Hugo Rojas-Romagosa (2010), 'The Relation Between Competition and Innovation: Empirical Results and Implementation into WorldScan', $C P B$ Memorandum. Den Haag: Netherlands Bureau for Economic Policy Analysis.

Impulliti, G. and Omar Licandro (2009), 'Trade, Firm Selection, and Innovation: The Competition Channel', Paper submitted to Workshop on Trade Firms Dynamics and Growth, June, 29-30 2009. Lucca: Institute for Advance Studies.

Levinsohn, James, and Amil Petrin (2003), 'Estimating Production Functions Using Inputs to Control for Unobservables', Review of Economic Studies 70(2), pp.317-341.

Licandro, O. and Antonio N. Ruiz (2010), 'Trade Liberalization, Competition and Growth', UFAE and IAE Working Papers 806.10, Barcelona: Unitat de Fonaments de l'Anàlisi Econòmica (UAB) and Institut d'Anàlisi Econòmica (CSIC).

Macapanpan, T. (1999), 'Private Sector Activities on R\&D', PIDS Discussion Paper No. 99-19, Makati City, Philippines.

Manasan, Rosario and Virginia Pineda (1999), 'Assessment of Philippine Tariff Reform: 1998 Update', AGILE Program Study Report. Manila: Philippines Institute for Development Studies.

Melitz, M. (2003), 'The Impact of Trade on Intra-Industry Reallocations and Aggregate Industry Productivity', Econometrica, 71(6), pp.1695-1725.

Nickell, S.J. (1996), 'Competition and Corporate Performance', Journal of Political Economy, 104(4), pp.724-46.

Olley, S. and Ariel Pakes (1996), 'The Dynamics of Productivity in the Telecommunications Equipment Industry', Econometrica 64, pp.1263-98. 
Organisation for Economic Co-operation and Development Secretariat (2007), Discussion Paper on Trade, Innovation and Growth. Paris: OECD.

Patalinghug, E. (2003), 'The Philippine Innovation System: Structure and Characteristics', PIDS Research Paper Series No. 2003-04, Makati City, Philippines.

Schumpeter, J. (1942), Capitalism, Socialism, and Democracy. New York: Harper.

Siotis, G. (2003), 'Competitive Pressure and Economic Integration: An Illustration for Spain, 1983-1996', International Journal of Industrial Organization, 21, pp.1435-1459. 


\section{Appendix}

\section{Appendix I: Price Cost Margin}

A.P Lerner (1933-34) defined PCM or Lerner index of monopoly power as:

$B=\frac{P-M C}{P} \quad$ equation (1a)

Where $B$ is price cost margin, $P$ is price, and $M C$ is marginal cost. For a competitive firm, $P=M C$ and the Lerner index is equal to zero. For a monopolist, $P>M C$ and the Lerner index becomes positive and varies between 0 and 1 .

The mark up ratio, a simple way of measuring the level of competition, is given by the ratio of price to marginal cost of production by firms in an industry. This can be written as:

$\mu=\frac{P}{M C} \quad$ equation $(1 \mathrm{~b})$

Where $\mu$ is the mark up ratio. This variable indicates the level of competition or market power of firms in industries. When firms have market power, $\mathrm{P}>\mathrm{MC}$ and mark ups are greater than 1 in equilibrium. In perfect competition, $\mathrm{P}=\mathrm{MC}$. The price cost margin can be easily mapped into the mark up ratio $\mu$. Equation (6) can be rewritten as:

$\mu=\frac{1}{1-B} \quad$ equation $(1 \mathrm{c})$ 


\section{ERIA Discussion Paper Series}

\begin{tabular}{|c|c|c|c|}
\hline No. & Author(s) & Title & Year \\
\hline $2012-05$ & Rafaelita M. ALDABA & $\begin{array}{l}\text { Trade Reforms, Competition, and Innovation in the } \\
\text { Philippines }\end{array}$ & $\begin{array}{l}\text { June } \\
2012\end{array}$ \\
\hline $2012-04$ & $\begin{array}{l}\text { Toshiyuki MATSUURA } \\
\text { and Kazunobu } \\
\text { HAYAKAWA }\end{array}$ & $\begin{array}{l}\text { The Role of Trade Costs in FDI Strategy of } \\
\text { Heterogeneous Firms: Evidence from Japanese Firm- } \\
\text { level Data }\end{array}$ & $\begin{array}{l}\text { June } \\
2012\end{array}$ \\
\hline $2012-03$ & $\begin{array}{l}\text { Kazunobu HAYAKAWA, } \\
\text { Fukunari KIMURA, and } \\
\text { Hyun-Hoon Lee }\end{array}$ & $\begin{array}{l}\text { How Does Country Risk Matter for Foreign Direct } \\
\text { Investment? }\end{array}$ & $\begin{array}{c}\text { Feb } \\
2012\end{array}$ \\
\hline $2012-02$ & $\begin{array}{l}\text { Ikumo ISONO, Satoru } \\
\text { KUMAGAI, Fukunari } \\
\text { KIMURA }\end{array}$ & $\begin{array}{l}\text { Agglomeration and Dispersion in China and ASEAN: } \\
\text { a Geographical Simulation Analysis }\end{array}$ & $\begin{array}{r}\text { Jan } \\
2012\end{array}$ \\
\hline 2012-01 & $\begin{array}{l}\text { Mitsuyo ANDO } \\
\text { and Fukunari KIMURA }\end{array}$ & $\begin{array}{l}\text { How Did the Japanese Exports Respond to Two } \\
\text { Crisesin the International Production Network?: } \\
\text { The Global Financial Crisis and the East Japan } \\
\text { Earthquake }\end{array}$ & $\begin{array}{c}\text { Jan } \\
2012\end{array}$ \\
\hline 2011-10 & $\begin{array}{l}\text { Tomohiro MACHIKITA } \\
\text { and Yasushi UEKI }\end{array}$ & $\begin{array}{l}\text { Interactive Learning-driven Innovation in } \\
\text { Upstream-Downstream Relations: Evidence from } \\
\text { Mutual Exchanges of Engineers in Developing } \\
\text { Economies }\end{array}$ & $\begin{array}{r}\text { Dec } \\
2011\end{array}$ \\
\hline 2011-09 & $\begin{array}{l}\text { Joseph D. ALBA, Wai- } \\
\text { Mun CHIA, and } \\
\text { Donghyun PARK }\end{array}$ & $\begin{array}{l}\text { Foreign Output Shocks and Monetary Policy } \\
\text { Regimes in Small Open Economies: } \\
\text { A DSGE Evaluation of East Asia }\end{array}$ & $\begin{array}{r}\text { Dec } \\
2011\end{array}$ \\
\hline 2011-08 & $\begin{array}{l}\text { Tomohiro MACHIKITA } \\
\text { and Yasushi UEKI }\end{array}$ & $\begin{array}{l}\text { Impacts of Incoming Knowledge on Product } \\
\text { Innovation: Econometric Case Studies of Technology } \\
\text { Transfer of Auto-related Industries in Developing } \\
\text { Economies }\end{array}$ & $\begin{array}{l}\text { Nov } \\
2011\end{array}$ \\
\hline 2011-07 & Yanrui WU & $\begin{array}{l}\text { Gas Market Integration: } \\
\text { Global Trends and Implications for the EAS Region }\end{array}$ & $\begin{array}{l}\text { Nov } \\
2011\end{array}$ \\
\hline 2011-06 & Philip Andrews-SPEED & $\begin{array}{l}\text { Energy Market Integration in East Asia: } \\
\text { A Regional Public Goods Approach }\end{array}$ & $\begin{array}{l}\text { Nov } \\
2011\end{array}$ \\
\hline 2011-05 & $\begin{array}{l}\text { Yu SHENG, } \\
\text { Xunpeng SHI }\end{array}$ & $\begin{array}{l}\text { Energy Market Integration and Economic } \\
\text { Convergence: } \\
\text { Implications for East Asia }\end{array}$ & $\begin{array}{r}\text { Oct } \\
2011\end{array}$ \\
\hline
\end{tabular}




\begin{tabular}{|c|c|c|c|}
\hline 2011-04 & $\begin{array}{l}\text { Sang-Hyop LEE, Andrew } \\
\text { MASON, and Donghyun } \\
\text { PARK }\end{array}$ & $\begin{array}{l}\text { Why Does Population Aging Matter So Much for } \\
\text { Asia? } \\
\text { Population Aging, Economic Security and } \\
\text { Economic Growth in Asia }\end{array}$ & $\begin{array}{l}\text { Aug } \\
2011\end{array}$ \\
\hline 2011-03 & $\begin{array}{l}\text { Xunpeng SHI, } \\
\text { Shinichi GOTO }\end{array}$ & $\begin{array}{l}\text { Harmonizing Biodiesel Fuel Standards in East Asia: } \\
\text { Current Status, Challenges and the Way Forward }\end{array}$ & $\begin{array}{l}\text { May } \\
2011\end{array}$ \\
\hline 2011-02 & Hikari ISHIDO & $\begin{array}{l}\text { Liberalization of Trade in Services under ASEAN }+n \text { : } \\
\text { A Mapping Exercise }\end{array}$ & $\begin{array}{l}\text { May } \\
2011\end{array}$ \\
\hline 2011-01 & $\begin{array}{l}\text { Kuo-I CHANG, } \\
\text { Kazunobu HAYAKAWA } \\
\text { Toshiyuki MATSUURA }\end{array}$ & $\begin{array}{l}\text { Location Choice of Multinational Enterprises in } \\
\text { China: Comparison between Japan and Taiwan }\end{array}$ & $\begin{array}{l}\text { Mar } \\
2011\end{array}$ \\
\hline $2010-11$ & $\begin{array}{l}\text { Charles HARVIE, } \\
\text { Dionisius NARJOKO, } \\
\text { Sothea OUM }\end{array}$ & $\begin{array}{l}\text { Firm Characteristic Determinants of SME } \\
\text { Participation in Production Networks }\end{array}$ & $\begin{array}{l}\text { Oct } \\
2010\end{array}$ \\
\hline $2010-10$ & Mitsuyo ANDO & $\begin{array}{l}\text { Machinery Trade in East Asia, and the Global } \\
\text { Financial Crisis }\end{array}$ & $\begin{array}{l}\text { Oct } \\
2010\end{array}$ \\
\hline 2010-09 & $\begin{array}{l}\text { Fukunari KIMURA } \\
\text { Ayako OBASHI }\end{array}$ & $\begin{array}{l}\text { International Production Networks in Machinery } \\
\text { Industries: Structure and Its Evolution }\end{array}$ & $\begin{array}{l}\text { Sep } \\
2010\end{array}$ \\
\hline $2010-08$ & $\begin{array}{l}\text { Tomohiro MACHIKITA, } \\
\text { Shoichi MIYAHARA, } \\
\text { Masatsugu TSUJI, and } \\
\text { Yasushi UEKI }\end{array}$ & $\begin{array}{l}\text { Detecting Effective Knowledge Sources in Product } \\
\text { Innovation: Evidence from Local Firms and } \\
\text { MNCs/JVs in Southeast Asia }\end{array}$ & $\begin{array}{l}\text { Aug } \\
2010\end{array}$ \\
\hline 2010-07 & $\begin{array}{l}\text { Tomohiro MACHIKITA, } \\
\text { Masatsugu TSUJI, and } \\
\text { Yasushi UEKI }\end{array}$ & $\begin{array}{l}\text { How ICTs Raise Manufacturing Performance: Firm- } \\
\text { level Evidence in Southeast Asia }\end{array}$ & $\begin{array}{l}\text { Aug } \\
2010\end{array}$ \\
\hline $2010-06$ & Xunpeng SHI & $\begin{array}{l}\text { Carbon Footprint Labeling Activities in the East Asia } \\
\text { Summit Region: Spillover Effects to Less Developed } \\
\text { Countries }\end{array}$ & $\begin{array}{l}\text { July } \\
2010\end{array}$ \\
\hline $2010-05$ & $\begin{array}{l}\text { Kazunobu HAYAKAWA, } \\
\text { Fukunari KIMURA, and } \\
\text { Tomohiro MACHIKITA }\end{array}$ & $\begin{array}{l}\text { Firm-level Analysis of Globalization: A Survey of } \\
\text { the Eight Literatures }\end{array}$ & $\begin{array}{l}\text { Mar } \\
2010\end{array}$ \\
\hline 2010-04 & $\begin{array}{l}\text { Tomohiro MACHIKITA } \\
\text { and Yasushi UEKI }\end{array}$ & $\begin{array}{l}\text { The Impacts of Face-to-face and Frequent } \\
\text { Interactions on Innovation: } \\
\text { Upstream-Downstream Relations }\end{array}$ & $\begin{array}{l}\text { Feb } \\
2010\end{array}$ \\
\hline $2010-03$ & $\begin{array}{l}\text { Tomohiro MACHIKITA } \\
\text { and Yasushi UEKI }\end{array}$ & $\begin{array}{l}\text { Innovation in Linked and Non-linked Firms: } \\
\text { Effects of Variety of Linkages in East Asia }\end{array}$ & $\begin{array}{l}\text { Feb } \\
2010\end{array}$ \\
\hline
\end{tabular}




\begin{tabular}{|c|c|c|c|}
\hline $2010-02$ & $\begin{array}{l}\text { Tomohiro MACHIKITA } \\
\text { and Yasushi UEKI }\end{array}$ & $\begin{array}{l}\text { Search-theoretic Approach to Securing New } \\
\text { Suppliers: Impacts of Geographic Proximity for } \\
\text { Importer and Non-importer }\end{array}$ & $\begin{array}{l}\text { Feb } \\
2010\end{array}$ \\
\hline $2010-01$ & $\begin{array}{l}\text { Tomohiro MACHIKITA } \\
\text { and Yasushi UEKI }\end{array}$ & $\begin{array}{l}\text { Spatial Architecture of the Production Networks in } \\
\text { Southeast Asia: } \\
\text { Empirical Evidence from Firm-level Data }\end{array}$ & $\begin{array}{l}\text { Feb } \\
2010\end{array}$ \\
\hline $2009-23$ & Dionisius NARJOKO & $\begin{array}{l}\text { Foreign Presence Spillovers and Firms' Export } \\
\text { Response: } \\
\text { Evidence from the Indonesian Manufacturing }\end{array}$ & $\begin{array}{l}\text { Nov } \\
2009\end{array}$ \\
\hline $2009-22$ & $\begin{array}{l}\text { Kazunobu HAYAKAWA, } \\
\text { Daisuke HIRATSUKA, } \\
\text { Kohei SHIINO, and } \\
\text { Seiya SUKEGAWA }\end{array}$ & Who Uses Free Trade Agreements? & $\begin{array}{l}\text { Nov } \\
2009\end{array}$ \\
\hline $2009-21$ & Ayako OBASHI & $\begin{array}{l}\text { Resiliency of Production Networks in Asia: } \\
\text { Evidence from the Asian Crisis }\end{array}$ & $\begin{array}{c}\text { Oct } \\
2009\end{array}$ \\
\hline $2009-20$ & $\begin{array}{l}\text { Mitsuyo ANDO and } \\
\text { Fukunari KIMURA }\end{array}$ & Fragmentation in East Asia: Further Evidence & $\begin{array}{c}\text { Oct } \\
2009\end{array}$ \\
\hline 2009-19 & Xunpeng SHI & $\begin{array}{l}\text { The Prospects for Coal: } \\
\text { Global Experience and Implications for Energy } \\
\text { Policy }\end{array}$ & $\begin{array}{l}\text { Sept } \\
2009\end{array}$ \\
\hline $2009-18$ & Sothea OUM & $\begin{array}{l}\text { Income Distribution and Poverty in a CGE } \\
\text { Framework: A Proposed Methodology }\end{array}$ & $\begin{array}{c}\text { Jun } \\
2009\end{array}$ \\
\hline $2009-17$ & $\begin{array}{l}\text { Erlinda M. MEDALLA } \\
\text { and Jenny BALBOA }\end{array}$ & $\begin{array}{l}\text { ASEAN Rules of Origin: } \\
\text { Lessons and Recommendations for the Best Practice }\end{array}$ & $\begin{array}{c}\text { Jun } \\
2009\end{array}$ \\
\hline $2009-16$ & Masami ISHIDA & Special Economic Zones and Economic Corridors & $\begin{array}{c}\text { Jun } \\
2009\end{array}$ \\
\hline $2009-15$ & Toshihiro KUDO & $\begin{array}{l}\text { Border Area Development in the GMS: } \\
\text { Turning the Periphery into the Center of Growth }\end{array}$ & $\begin{array}{l}\text { May } \\
2009\end{array}$ \\
\hline $2009-14$ & $\begin{array}{l}\text { Claire HOLLWEG and } \\
\text { Marn-Heong WONG }\end{array}$ & $\begin{array}{l}\text { Measuring Regulatory Restrictions in Logistics } \\
\text { Services }\end{array}$ & $\begin{array}{c}\text { Apr } \\
2009\end{array}$ \\
\hline $2009-13$ & Loreli C. De DIOS & Business View on Trade Facilitation & $\begin{array}{c}\text { Apr } \\
2009\end{array}$ \\
\hline $2009-12$ & $\begin{array}{l}\text { Patricia SOURDIN and } \\
\text { Richard POMFRET }\end{array}$ & Monitoring Trade Costs in Southeast Asia & $\begin{array}{c}\text { Apr } \\
2009\end{array}$ \\
\hline $2009-11$ & $\begin{array}{l}\text { Philippa DEE and } \\
\text { Huong DINH }\end{array}$ & $\begin{array}{l}\text { Barriers to Trade in Health and Financial Services in } \\
\text { ASEAN }\end{array}$ & $\begin{array}{c}\text { Apr } \\
2009\end{array}$ \\
\hline
\end{tabular}




\begin{tabular}{|c|c|c|c|}
\hline 2009-10 & Sayuri SHIRAI & $\begin{array}{l}\text { The Impact of the US Subprime Mortgage Crisis on } \\
\text { the World and East Asia: Through Analyses of Cross- } \\
\text { border Capital Movements }\end{array}$ & $\begin{array}{c}\text { Apr } \\
2009\end{array}$ \\
\hline 2009-09 & $\begin{array}{l}\text { Mitsuyo ANDO and } \\
\text { Akie IRIYAMA }\end{array}$ & $\begin{array}{l}\text { International Production Networks and Export/Import } \\
\text { Responsiveness to Exchange Rates: } \\
\text { The Case of Japanese Manufacturing Firms }\end{array}$ & $\begin{array}{l}\text { Mar } \\
2009\end{array}$ \\
\hline 2009-08 & $\begin{array}{l}\text { Archanun } \\
\text { KOHPAIBOON }\end{array}$ & $\begin{array}{l}\text { Vertical and Horizontal FDI Technology Spillovers: } \\
\text { Evidence from Thai Manufacturing }\end{array}$ & $\begin{array}{l}\text { Mar } \\
2009\end{array}$ \\
\hline 2009-07 & $\begin{array}{l}\text { Kazunobu HAYAKAWA, } \\
\text { Fukunari KIMURA, and } \\
\text { Toshiyuki MATSUURA }\end{array}$ & $\begin{array}{l}\text { Gains from Fragmentation at the Firm Level: } \\
\text { Evidence from Japanese Multinationals in East Asia }\end{array}$ & $\begin{array}{l}\text { Mar } \\
2009\end{array}$ \\
\hline 2009-06 & Dionisius A. NARJOKO & $\begin{array}{l}\text { Plant Entry in a More Liberalised Industrialisation } \\
\text { Process: An Experience of Indonesian } \\
\text { Manufacturing during the } 1990 \mathrm{~s}\end{array}$ & $\begin{array}{l}\text { Mar } \\
2009\end{array}$ \\
\hline 2009-05 & $\begin{array}{l}\text { Kazunobu HAYAKAWA, } \\
\text { Fukunari KIMURA, and } \\
\text { Tomohiro MACHIKITA }\end{array}$ & Firm-level Analysis of Globalization: A Survey & $\begin{array}{l}\text { Mar } \\
2009\end{array}$ \\
\hline 2009-04 & $\begin{array}{l}\text { Chin Hee HAHN and } \\
\text { Chang-Gyun PARK }\end{array}$ & $\begin{array}{l}\text { Learning-by-exporting in Korean Manufacturing: } \\
\text { A Plant-level Analysis }\end{array}$ & $\begin{array}{l}\text { Mar } \\
2009\end{array}$ \\
\hline 2009-03 & Ayako OBASHI & $\begin{array}{l}\text { Stability of Production Networks in East Asia: } \\
\text { Duration and Survival of Trade }\end{array}$ & $\begin{array}{l}\text { Mar } \\
2009\end{array}$ \\
\hline 2009-02 & Fukunari KIMURA & $\begin{array}{l}\text { The Spatial Structure of Production/Distribution } \\
\text { Networks and Its Implication for Technology } \\
\text { Transfers and Spillovers }\end{array}$ & $\begin{array}{l}\text { Mar } \\
2009\end{array}$ \\
\hline 2009-01 & $\begin{array}{l}\text { Fukunari KIMURA and } \\
\text { Ayako OBASHI }\end{array}$ & $\begin{array}{l}\text { International Production Networks: } \\
\text { Comparison between China and ASEAN }\end{array}$ & $\begin{array}{c}\text { Jan } \\
2009\end{array}$ \\
\hline 2008-03 & $\begin{array}{l}\text { Kazunobu HAYAKAWA } \\
\text { and Fukunari KIMURA }\end{array}$ & $\begin{array}{l}\text { The Effect of Exchange Rate Volatility on } \\
\text { International Trade in East Asia }\end{array}$ & $\begin{array}{c}\text { Dec } \\
2008\end{array}$ \\
\hline 2008-02 & $\begin{array}{l}\text { Satoru KUMAGAI, } \\
\text { Toshitaka GOKAN, } \\
\text { Ikumo ISONO, and } \\
\text { Souknilanh KEOLA }\end{array}$ & $\begin{array}{l}\text { Predicting Long-Term Effects of Infrastructure } \\
\text { Development Projects in Continental South East } \\
\text { Asia: IDE Geographical Simulation Model }\end{array}$ & $\begin{array}{c}\text { Dec } \\
2008\end{array}$ \\
\hline 2008-01 & $\begin{array}{l}\text { Kazunobu HAYAKAWA, } \\
\text { Fukunari KIMURA, and } \\
\text { Tomohiro MACHIKITA }\end{array}$ & Firm-level Analysis of Globalization: A Survey & $\begin{array}{c}\text { Dec } \\
2008\end{array}$ \\
\hline
\end{tabular}

